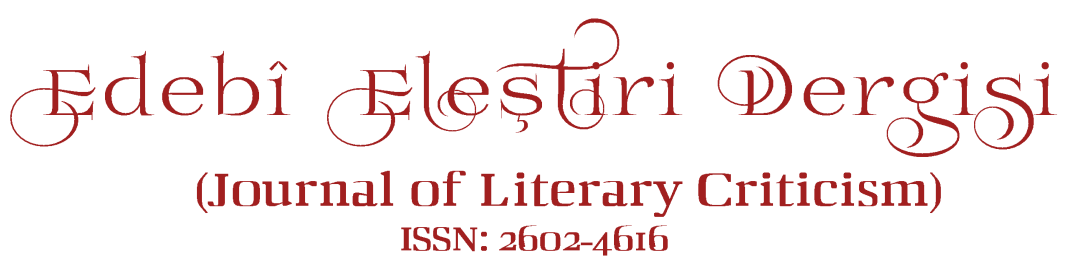

Cilt II, Sayı I, Nisan 2018

YÜKLENME TARIHI: 03.04.2018 KABUL TARIIHI: 23.04.2018 YAYIN TARİHI: 30.04.2018

\author{
Özkan CİĞA \\ Dr., Dicle Üniversitesi Ziya Gökalp \\ Eğitim Fakültesi Türkçe ve Sosyal \\ Bilimler Eğitimi Bölümü Türk Dili ve \\ Edebiyatı Eğitimi AnabilimDalı \\ ozkanciga@gmail.com ORCID: \\ 00000002-7081-4507
}

\section{KISSA-İ SEYYİD CÜNEYD VE REŞÎDE-İ ARAB'DA SOSYAL HAYATA DAİR UNSURLAR*}

\author{
ELEMENTS OF SOCIAL LIFE IN \\ KISSA-İ SEYYID CÜNEYD VE \\ REŞÎDE-İ ARAB
}

\section{ÖZ}

Asırlar öncesinde yaşamış toplulukların sosyal ve kültürel mirasının izini sürmek adına incelenen tarîhî eserlerin yanı sıra edebî eserlerin de önemi inkâr edilemez. Edebî eserlerde, geçmişteki toplumların k1lı kıyafetlerine, yeme içmelerine, gündelik ihtiyacı kolaylaştırmak adına kullandıkları araç gereçlerine, gelenekgöreneklerine ve yaşam tarzlarına dair izler görmek mümkündür. Sosyal hayata dair izler taşıyan bu edebî eserlerden biri de XVI. yüzyılda Farsçadan Türkçeye tercüme edilmiş Kıssa-i Seyyid Cüneyd ve Reşîde-i Arab, adlı mensur hikâyedir. Müellifinin kim olduğu hakkında kesin bir hükme varılamayan bu eser, Seyyid Cüneyd ile Reşîde-i Arab'ın arasındaki aşk1, birbirlerine kavuşmak için yaşadıkları zorlu mücadeleyi ve onları bulmaya çalışan şahısların macerasını konu edinir. Hikâye, birtakım ahlâkî değerleri ve halk inançlarını öğretme, tarih ve insan sevgisini anlatma ve benimsetme açısından oldukça zengin bir içeriğe sahiptir. Birbiriyle bağlantılı olayların yer aldığı çerçeve hikâye tarzında kaleme alınan bu eserde, olağanüstü varlık, mekân ve olayların yanı sıra tarihî şahıs, mekân ve olaylar bir arada bulunur. Bu çalışmada, olayların seyrine göre değișen toplumların yaşam tarzına dair izlenimlerin yer aldığı Kıssa-i Seyyid Cüneyd ve Reşîde-i Arab'da sosyal hayata dair meslek, sanat, kılık kıyafet, araç gereç, ziyafet ve düğün
It is not denied literary work's importance as well as historical works, which they reflect to social and cultural heritage of communities that lived centuries ago. It is possible to observe old communities's life style, their costumes, their eating and drinking and their tools that they use them to help. One of the literary works that it brings signs about social life is K1ssa-i Seyyid Cüneyd ve Reşîde-i Arab which it translated Persian to Turkish in sixteenth century. This work that it is not known its author tolds Seyyid Cüneyd and Reşîde-i Arab's love, their hard struggle to reach each other and persons who try to find them. This story has a rich content in terms of theaching some moral values and folk beliefs, telling and getting people to accept the history and human love. In this work, which it was wrote up as frame tale collections, historical person, place and events are concurrent besides extraordinary presence, space and events. In this paper, it is to try to investigate material and spiritual elements of culture such as occupation, art, dress, equipment, feast and wedding ceremonies, folk beliefs and customs in Kıssa-i Seyyid Cüneyd and Reşide-i

\footnotetext{
* Bu çalışma, doktora tezimizden faydalanılarak hazırlanmıştır. Ayrıntılı bilgi için bk. Özkan Ciğa (2018). Kıssa-i Seyyid Cüneyd ve Reşîde-i Arab Tercümesi (Ínceleme-Metin). (Yayınlanmamış Doktora Tezi). Adıyaman: Adıyaman Üniversitesi SBE.
} 
Özkan CİĞA - Elements Of Social Life In Kıssa-i Seyyid Cüneyd ve Reşîde-i Arab

törenleri, halk inançları ve gelenek görenek gibi pek çok maddî ve manevî kültür unsurları incelenmeye çalışılacaktır.

Anahtar Kelimeler: Kissa-i Seyyid Cüneyd ve Reşîde-i Arab, Mensur Hikâye, Sosyal Hayat
Arab. Keywords: Kissa-i Seyyid Cüneyd and Reşide-i Arab, Prose Story, Social Life.

\section{Gíriş}

Klâsik Türk edebiyatı sahasında yapılan araştırmalara bakıldığında, özellikle dîvân şiirinin sosyal hayatla ilgisi üzerine çok sayıda tez, kitap, makale veya bildirilere rastlanır (Şen, 2007). Bu çalışmalar genellikle şahıs, dönem, nazım şekli veya konu çerçevesinde sosyal hayata dair unsurlar bağlamında ayrıntılı bir şekilde ele alınmıştır (Çavuşoğlu, 1971: 55-78; Dilçin, 1991: 114-127; Öbek, 1995; Kurnaz, 1996: 156-192; Tolasa, 2001: 96-132; Sefercioğlu, 2001: 76-120; Batislam, 2006; Serdaroğlu, 2006; Karataş, 2006; Özkan, 2007; Tuğluk, 2009 vb.). Klâsik Türk edebiyatında, sosyal hayat bağlamında dîvân şiiri üzerine yapılan bu çalışmaların yanı sıra -dîvân şiirine oranla az da olsa- mensûr olarak yazılan klâsik hikâyelerin tahlili sırasında da sosyal hayata değinildiği görülür (Çaldak, 2010; ÇakırKoncu: 2010; Erbay vd.: 2014; Arslan, 2015 vb.).

Sosyal hayatta ortak bir geçmişin sonucu olarak ortaya çıkan gelenek görenek, oyunlar, yiyecek ve içecekler, mûsikî âletleri, savaş âletleri, kılık kıyafet ve halk inançları gibi daha pek çok maddî ve manevî kültür unsurlarına, mensur olarak kaleme alınan Kissa-i Seyyid Cüneyd ve Reşîde-i Arab'da da rastlamak mümkündür. Müellifinin kim olduğu hakkında kesin bir hükme varılamayan bu eser, XVI. yüzyılda Farsçadan Türkçeye tercüme edilmiştir. Bu eserin, biri İstanbul Üniversitesi Nadir Eserler Kütüphanesinde diğeri ise Süleymaniye Yazma Eserler Kütüphanesi Fatih koleksiyonunda olmak üzere iki nüshasına ulaşılmıştır. İstanbul Üniversitesi Nadir Eserler Kütüphanesinde yer alan tercümenin mütercimi Vâhidî, Süleymaniye Yazma Eserler Kütüphanesinde bulunan tercümenin mütercimi ise Yahyâ b. Abdullâh El-Çerkesî'dir (Ciğa, 2018; 4-10). Eserde râvî olarak yer alan Ebû Hafs-1 Kûfî tarafindan anlatılan bu hikâye, aslında Hârûn Reşî́d'in yakalandığ 1 hastalıktan kurtulup şifa bulması amaciyla anlatıldığı dile getirilir (Ciğa, 2018; 169-170). Hikâyenin asıl kahramanları Seyyid Cüneyd ile Reşîde-i Arab'dır. Seyyid Cüneyd ile Reşîde-i Arab bir savaş meydanında iki düşman askeri olarak karşılaşır ve bir süre savaştıktan sonra birbirlerine âşı olur. Bu ikili arasında başlayan aşk neticesinde uzun ve efsanevî bir macera ortaya çıkar. Hikâyenin asıl kahramanları etrafında teşekkül eden olaylara ve onları aramak için yola çıkan yardımcı şahısların başından geçen maceralara bakılırsa eserin, birbiriyle bağlantılı olayların yer aldığı Sinbadnâme, Binbir Gece Masalları, Kırk Vezir Hikâyeleri gibi çerçeve hikâye tarzında kaleme alındığı görülür. Hikâyede cin, peri, şeytan, cadı gibi olağanüstü şahıslara yer verildiği gibi dînî ve tarihî şahsiyetler de hikâyenin kurgu dünyasına dâhil edilir. Fantastik öğelerin de yer aldığı 
hikâyede şahıs, duygu, olay, çevre veya mekânların tasviri sırasında bazen ayrıntıya olabildiğince yer verilir. Hikâyede, günümüz hikâyelerine atfedilen bazı anlatım tekniklerinin de kullanıldığı ve bu yönüyle hikâyenin güçlü bir tahkiye yapısına sahip olduğu görülür. Bulunduğu döneme göre sade bir dille yazılan eser, Eski Anadolu Türkçesinin dil hususiyetlerini barındırmakta ve buna bağlı olarak arkaik kelimeler, deyim ve atasözleri bakımından zengindir (Ciğa, 2018). Hikâyedeki olayların birbirinden farklı kültüre ve inanca sahip ülke, şehir veya mekânlarda cereyan etmesi nedeniyle hikâyede, sosyal hayata dair ilgi çekici pek çok unsurun yer aldığı görülür. Hikâyede yer alan sosyal hayata dair unsurlardan bir kısmını ayrı başlıklar halinde şöyle sıralamak mümkündür:

\section{Savaş ve Savaş Âletleri}

Hikâyedeki kahramanların ve toplulukların olabildiğince aktif olmaları nedeniyle hikâyede, savaşçılık, avcılık gibi hareket kabiliyeti gerektiren bir yaşam kültürü mevcuttur. Hikâyede, av sırasında tartıştığ 1 kişiyi öldüren Seyyid Cüneyd, daha sonra gelişecek olayların fitilini ateşler. Reşîde'nin hikâyede ortaya çıkmasının ardından onun uğruna yapılan pek çok savaşın ve ikili mücadelenin yaşandığı hikâyede çoğu zaman savaşa dair unsurlara rastlamak mümkündür. Savaştan önce yapılan hazırlıklar, iki düşman askerin birbirlerine meydan okuması, and içme, savaş âletleri, savaş sırasında yapılan hileler, yapılan savaşın şiddetini, şeklini anlatan tasvîrler ve buna benzer pek çok unsur hikâyede yer alır.

Savaş başlamadan önce askerler savaş meydanına gelerek saf saf dizilir, kösler ve davullar çalınır ve savaş naraları atılarak meydana er taleb edilir. $\mathrm{Bu}$ er genellikle üstün savaş kabiliyeti olan kişidir. Karşılıklı ikili mücadelenin galibi belli olana kadar erler meydana teker teker çıkar ve savaşır. Her iki taraf anlaşma yoluna giderse savaştan vazgeçilir. Ama anlaşma gerçekleşmezse on binlerce nefer büyük bir mücadele içine girerek savaşır. şöyledir':

Hikâyede yer alan bir kısım savaş motiflerini gösteren tasvîrler

“... Ol leşker dahı fevc fevc cavk cavk gürūh gürūh alay alay șaf șaf ārāyī itdiler ve iki cānibden kūs-1 harbīler ve țabl-1 ḍarbīler çaldılar... (Ciğa, 2018: 240)"

“... iki leşkerden kūs-1 sulțāni ve țabl-1 hāḳānī dögülüp mașāfgāha yüz țutdılar ve kalb-1 cenāḥı ārāste itdiler. Meymene vü meysereyi pīrāste ḳılup naẓar ber-meydān itdiler ki iki cānibden meydāna merdāne kim sebḳat eyleye veyā kim şecā'at göstere. Nā-gāh Benī-Şeybān sipāhından Merre-nām bir süvār meydāna girdi. Cevelān gösterüp er diledi. Medīne ' askerinden Ġālib-nām bir dil-āver āheng-i meydān itdi țarìi idüp cevelān gösterdi... (178)"

\footnotetext{
${ }^{1}$ Söz konusu hikâyeden sosyal hayata dair alınan örnekler çoğaltılabilir. Ancak çalışmanın kapsamı ve amacı nedeniyle örnekler sınırlı tutulmuştur.

2 Örnek metinler, aynı kaynaktan alındığı için bundan sonraki alıntılarda sadece sayfa numaraları yer alacaktır.
} 
Özkan CİĞA - Elements Of Social Life In Kıssa-i Seyyid Cüneyd ve Reşîde-i

Arab

“... Ba' de Benī-Şeybān leşkerine karşu turup Hamzavār ol merd-i server derūn-1 dilden bir na' ra-i bülend urdı ki țās-1 ḳubbe-i feleki çökertdi ve iki leşker ḩalḳı serāsime olup nicesi bī-hūş atından düşdi ve atları daḩı süheyl urup üzerindekin yire bıraḳdı, rāh-1 beyābānı țutd1... (179)"

Hikâyede özellikle ikili mücadeledeki tasvîrler dikkat çeker. Bu tasvîrlerde, kahramanlar tarafından atılan savaş naraları, kırılan kılıç ve mızraklar, çekilen yaylar ve firlatılan okların saplandığ yerler, dövüş sırasında kahramanların birbirini kızdırmak için söylediği kötü sözler, kahramanların dövüşten yorulup kan içinde kaldıklarını gösteren tasvirler ve buna benzer pek çok anlatımlar mevcuttur:

“... Bu mühmelātdan şîr-i şerze gibi bī-ihtiyār üzerine hamle eyledi ve ol dahı bunuñ hamlesine üzerine karşu geldi ve birbiriyle haylī tutuşdılar ve āhir ellerine tịg $-i$ tỉz alup hūn-rīzlige kașd itdiler ve birbirlerine şol ḳadar tīg uruşdılar ki ammā kendülerine hațā gelmeyüp tìg tìge tokunmaḳdan ellerinde tịg şikest oldı. Çün tìglerin bir yire bıragup birbirinüñ kemerinden țutuşdılar. İki ejderha gibi birbirlerine șarmaşdılar. Keş-ā-keşde iken nā-gāh ol şahş-1 zūr-kār bir hancer-i ābdār ile Cüneyd'üñ elini mecrūḥ eyledi. Cüneyd çün anı gördi, ġażaba geldi. Şöyle kuvvet ḳıldı kim ol şahșı yirden kaldurup bālā-yı ser atdı. Andan șoñra zīr ü zeber kıldı. Ol şahșuñ iñüleri hurd oldı ve kendüsi mürd oldı. Cüneyd ġāyetde gażabından başına birḳaç püşt-pā urup helāk ḳıldı... (174-175)"

Savaşlarda ok/tîr, yay/kemân, k1liç/tî̆ğşemşîr, nîmçe-i piyâdegân, gürz, kemend, hançer, mızrak/nîze kullanılır, savaşçılar zırh/ cebe/ cevşen/ dır' giyer ve başlarında ışık, ellerinde kalkan bulunur. Savaşçıların atları ise zırhla kaplıdır. Eğer bir kalenin surları veya yüksek bir yer yıkılacaksa yanlarında mancınıklar ve silâhları, külüng-zenleri taşıyan arabalar vardır:

“... Çün cebe-hāaneyi buldılar, ḳapusını açup içerü girdiler. Gördiler ki oḳuñ ve yayuñ ve ḳllı̧̧uñ ve hancerüñ ve cebenüñ ve cevşenüñ nihāyeti yoḳ. Muhtār yüz tīr ve bir kemān bir şemşīr ve bir ḳırban ve bir zırh ve nimmçe-i piyādegān alup Kāạịi'yle ḳayșerüñ kașrından şehrden țaşraya revāne oldılar tā şol harābeye irdiler ki Şeybū dimişdi aña girüp oturdılar... (268-269)"

“... ol ḩavāric-i mel' ūn gelüp bir 'araba düzdi. Şöyle ki altına on kişi girüp gizlenürdi. Şöyle ki menāreden ol 'araba üzerine hezār țaş düşerse dahı altundaġılara mużırrat irişmezdi. Külüng-zenler ol ' arabanuñ altına girüp oturdılar. Ol 'arabayı güçile çeküp menāre dibine iletdiler. Külüng-zenler dahı menāreyi dibinden bozmaġa başladılar... (616)"

Savaştan önce iki düşman askeri veya hükümdarlar öc almak için and içer ve birbirlerine meydan okur. $\mathrm{Bu}$ tarz konuşmaların yaşandığ 1 tasvîrler hikâyede hemen her savaş veya ikili mücadele başlamadan önce yer alır:

“... Gürgsār, Cüneyd'i kendü yanında kalilï̈’l-vücūd ta'accüb idüp eyitdi: Ey civān niçün miḳdāruño bilmezsin? Utanmadan benüm meydānuma dahıı girürsin ki eger Ḥamza zinde olaydı baña bende olup 
gāaş̧yedārum olurdı. Sen ḳandın benümle āheng-i ceng itmek ḳandın. Seyyid Cüneyd eyitdi: Sen herze söyleme ve erenlerüñ adını kemlik ile yād itme ki ben ol Ḥamza-i nāmdāruñ kemter gulāmıyın. Heminsā̄ at seni bir lư bla helāk idem kim tā rūz-1 ḳıāmet dek illerde ad olup dillerde yād ola diyüp hemān amān u zamān virmeyüp ḥamle eylediler...(459)"

Savaş başlamadan önce kimi zaman savaşçıların veya ordunun fiziki özellikleri, kabiliyetleri, güçleri, cesaretleri ve varsa olağanüstü özellikleri mübalağalı bir şekilde anlatılır:

“... Ol țarafdan çün Kurās silāḥın giyüp andan meydāna girdi ki bir pādişāhda anuñ gibi silāḥ yog̣dı ve eyidürler ki ol silāḥ Ferīdūn'uñ gencinden çıḳmışdı ki anı āteş yaḳmazdı ve āb ıṣlamazdı ve hịç zahm aña kar itmezdi ve ba' żllar eyidürler ki İsfendiyār'uñ silāḥıdı. Andan eyidürler ki İsfendiyār-1 Rūyīn-tenüñ silāḥydı. Ammā bu silạ̣̄ sebeble Rūyīn-ten eyidürler idi. Çün Kurās bu silāḥı giydi bu Kurās bir büyük şahșdı ki at anı götürmezdi. Meger ol at pil-ten olaydı, didi ve bir büyük atı var idi. Hemān ol götürürdi. Dā’imāa aña süvār olurdı. Ol mel' ūnuñ ḳ̂rḳ beş arşun ḳadd u ḳāmeti var idi ve cesāmeti aña göre idi. Bir ḳara țag gibi çün yirinden ḳopdı, meydāna Muhtār'a çünberāber țurd1... (702-704)"

Hikâyede yer alan pek çok savaş sahnesinde kimi zaman orduların ihtişâmı veya şiddetli bir şekilde çarpışma anları mübalağalı bir anlatım ile sunulur. Gece olunca veya dinlenme ihitiyacı doğunca tabl-1 âsâyişler çalınırak savaşa ara verilir. Savaşa ara verildikten sonra kazanan ve yenilen taraflar belirlenir:

“... Be-nā-çār tabl-ı āsāyiş çalındı iki leşker birbirinden bölündi, varup mekānlarına gelindi ve bahādırlı̣ kim itdi ve kim itmedi bilindi... (181)"

“... Çün güneş țulundı iki 'askerden țabl-1 āsāyiş çalındı. İki leşker birbirinden bölindi kim öldi ve kim ölmedi bilindi... (185)"

“... țabl-1 āsāyiş çalındı. Cengden el çekilüp bölündi ve merdānelik kim itdi ve kim itmedi bilindi ve her kişi ḩaymesine gelüp dölendi... (460)"

Ok ve yay geçmişte bir savaş âleti olarak kullanılmasının yanı sıra günümüzde olduğu gibi bir spor âleti olarak da kullanılır (Ayanoğlu, 1974; İnan, 1992). Yay çekip ok atmak geçmişte yiğitliğin ve kahramanlığın bir nişanı olarak görülürdü. Bu nedenle hikâyede bir kahraman övüldüğü sırada onun ok ve yay kullanmadaki ustalığından da bahsedilir. Örneğin Seyyid Cüneyd'in henüz genç yaşta kullandığı kemânın kirişini kimse kımıldatamaz durumdadir:

“... esb-i tāzīlere süvār olup şikār hevesin itdi ve çün on beş yaşına irdi, hịç kimse anuñ kemānı kirişin yirinden ḳımıldadamaz idi... (173)"

Hikâyede yeri geldikçe; çok genç yaşta yay çekip ok atmayı öğrenen Seyyid Cüneyd'in, kız olmasına rağmen ok ve yay kullanmada en az Seyyid Cüneyd kadar mahir olan Reşîde-i Arab’1n, Sa'd-1 Vakkâs'ın torunu olan ve ok atmada dedesinin nâmını devam ettiren Muhtâr-ı tîrdârın savaş veya 
avlanma sırasında okçuluktaki hünerleri anlatılır. Kahramanların hünerleri anlatıllırken okçuluğa dair pek çok terime de yer verilir. Ok atan kişinin ustalığını belirtmek için "tîr-endâz, tîrdâr, tîrzen"; okluk olarak kullanılan ok kabı için "terkeş, kırban", okun hedefe kilitlendiğini anlatmak için "şast-1 dürüst, nazar-1 savâb, nişân, gez/ gezle-", yayın ve okun parçalarını belirten "kiriş, yelek" ifadeleri kullanılır:

“... Cüneyd dahı hemān kemānı̃ eline alup kırbanından tīr-i elmāspeykān çıḳardı. Hुāne-i kemāna ḳoyup nişāna ḳașd itdi dahıhı naẓar-ı șavāb idüp şaștdan tīr halāṣs-1 pertāb ḳılup her oḳ ki yayından çıḳdı nişāna düşdi. Ya' nī sīne-i düşmene oturdı. Çün otuz oḳ atdı otuz harāmīi öldürdi... (229)"

“... Muhtār eyitdi: Lațifeyi ḳo hele kenārdan gözle diyüp oḳı gezledi. Şeybū gāyet bīmden bir ' azị̄m ag̉aca çıḳdı. Muhtār-1 tî̀rār tỉz kemāna ok ḳodı. Naẓar-1 șavābla nişāna pertāb itdi, ya'nī arslanuñ pīşānına...

(249)"

Hikâyedeki savaş ve avlanma sahnelerinde sıkça adından bahsedilen ok ve yay kimi zaman dünya dolusu altından daha değerlidir:

“... Muhtār eyitdi: Yola gitmege sebeb sāz selebdür. Hemīn zeheb degüldür. Kayșerüñ cebe-hānesin bulalum. Murādumuzca yarak alalum ki baña dünyā țolusı sìm zerden oḳ ve yay bihterdür didi... (268)"

Hikâyede Muhtâr, gittiği bir diyârda ok ve yay savaşını bilmeyen bir toplulukla karşılaşır ve bu durumu firsata çevirerek uzaktan gelen hemen her kişiyi öldürür. Yaralı olarak kurtulan bir kişi kendi padişahlarına varır. Bir savaş âleti olarak ok ve yay karşısındaki şaşkınlığını gizleyemeyen askerin daha sonra ok ve yayın nasıl bir savaş âleti olduğunu padişaha anlatması dikkat çekici bir husustur:

“... Çün siyāh bir kez āh idüp ol dahı cān cehenneme ıșmarladı ve kalan zengiler tīr ü kemān görmiş degüller idi. Muhtār'uñ kārında 'acebe kaldılar ve eyitdiler: Ey kişi biz bunuñ gibi işi hergiz bu ucı demürli ag̉acı bilmezüz ve andan görmiş dahı degülüz... (337)"

“...Ey şāh bil ve āgāh ol ki bir aḳ derili şahş gelmişdür. Elinde bir egri ag̉acı vardur. İki başı bir iple bag̉ludur başları ve bir doğnı ag̉acı daḩı ucı demürli ol ipli egri ag̉acına ḳor daḩı atar her biri atdukça bir ādemi helāk eyler... (340)"

\section{Avcillk}

Hikâyedeki kahramanlar, seyahat sırasında acıktıkları zaman veya kendilerini kuvvetli bir durumda hissettiklerinde hünerlerini göstermek için spor amaçlı ava çıkarlar. Av sırasında bazen yaban eşeği bazen de âhû avlarlar. Avladıkları hayvanları pişirerek yerler:

“...Ol șaḥrālarda arayup ikisi dah̆ı piyāde bād-1 seher gibi giderleridi ki ḳaçan kim acığlar şikāra bir gün birinüñ ve bir gün birinüñ bu ḳavl üzre gitdiler. Acıḳdılar nā-gāh öñlerinden bir āhū geçdi. Şeybū niçe gitdi ha diyince yetdi. Od yaḳup anı kebāb itdi. İkisi yidi... (249)"

“... Cüneyd ol ag̉açlardan ok yay düzüp ol āhūlardan düşürürdi. Hancerin țaşa çaḳardı āteş yaḳardı. Anı bişürürdi ve yirdi dahı havāda uçan ḳuşları oḳıla düşürür idi ve bişürüp anı dahı yirdi ve ba' de’ț- 
ța ām ol mīve-i ābdārlardan ifțār idüp ve Huzuā’ya şükr-güz̄ār olurdı...

(318-319)"

\section{Güreș Tutma/ Güreșçilik Sanatı}

Bir ata sporu olarak bilinen güreş hikâyede kimi zaman kendini ispat etme kaygısıyla, kimi zaman eş seçme amacıyla, kimi zaman da düşmana olan üstünlügünü gösterme ve hünerlerini sergileme amacıyla karşımıza çıkar. Kahramanların güç ve hünerlerini sergilediği bu spor için hikâyede bazı terimler kullanılır. Örneğin güreşin yapıldığı yer için "güreş meydanı", meydana girilmeden önce giyilen elbise için "câme-i sahtiyân/ sahtiyân tuman", güreş tutan kişiye verilen isim "pehlivân", sırtı yere gelen kişiye "püşti yire gel-, bas-" ifadeleri kullanılır:

“... Üseyd pehlevān er idi ve mübāriz server idi. Güreşcilik șan` atında kāmil idi, gāâil degüldi. Nā-gāh Üseyd, Esed'üñ iki țarafından Esed'üñ pehlūsın țutdı. Muhkem ḳuvvet idüp yirinden kapdı...(197)"

“... Cüneyd'üñ ġayreti țamarındaġı ḳanlar cūşa geldi, hemān-dem șoyund1. Saḩtiyān tumān giyüp 'azm-i meydān itdi ve cezm eyledi ki cümlesin bașa. Hulāyık Cüneyd'üñ kadd u kāāmetin ve șalābetin ve nehābetin görüp ta' accübde ḳaldılar...(235)"

Reşîde'yi gören benî-Hâşim gençleri ve Medîne pehlivânları Reşîde'yi elde edebilmek için kendi aralarında büyük bir mücadeleye girişirler. Büyük bir savaş eşiğine gelen Medîne halkı arasındaki bu fitneyi ortadan kaldırmak için Seyyid Üseyd, Reşîde'ye gelip bu civanlarla güreş tutmasını ister. Seyyid Üseyd, Reşîde'yi güreşte yenebilen pehlivân Reşîde'nin kocası olacağını ifade eder:

“... Ben̄i-Hāşim civānlarıyla ve Medīne pehlevānlarıyla bu meydānda güreşdürürin ve her kim ki seni bașarsa seni aña virürin ve sen aña 'avret olursın ve ol saña er olur. Duhter eyitdi: Ben bī-çāre nice eyyāmdur ki göñlümce ța'ām yimedüm egerçi açdum ve ammā cānumdan sīr idüm ve esīr-i bend-i zencīr idüm ḳıllet-i ḳuvvetden kuvvetüm ḳalmamışdur ve hem bir garībem ve 'avretem bu ḳadar ḩalāyıḳ-1 bì-gānenüñ meydānına lāyıḳ u revā görür misin? Üseyd'üñ ki bu sözler kulaġına girmedi. Elbette güreşmek gereksin didi. Duhter çār u nā-çār başından çārın çıḳardı, cāme-i saḩtiyān ve saḩtiyān țuman giyürdiler. Duhter gīsūların biline bag̉ladı ve pīrāhenin kemer ḳuşandı ve biline çin virüp āheng-i meydān itdi. Evvel Üseyd-i serverüñ öñine baş ḳoyup meydāna merdāne girdi ve miyāne-i meydānda țurdı. Evvel püser-zāde-i 'Amr 'Āṣ meydāna girdi duhterile țutuşdı. Duhter bir lu'bla anı baṣdı... (193-194)"

\section{Yiyecek ve İçecekler}

Kıssa-i Seyyid Cüneyd ve Reşîde-i Arab'da bağlama göre yiyecek ve içecek isimlerinin sık sık yer aldığını görmekteyiz. Yiyeceklerden koyun, sığır veya geyik etinden yapılan kebaplar/biryanlar, tavuk eti ve balıklar; darı veya normal undan yapılan ekmekler; helva, bal, yağlı çörek ve şeker börek 
Özkan CİĞA - Elements Of Social Life In Kıssa-i Seyyid Cüneyd ve Reşîde-i

Arab

şeklinde yapılan tatlılar; testilere doldurulmuş gülsuyları ile şekerli şerbetler; meclislerde içilen şaraplar; findık, fıstık, badem, kuru üzüm (nukl) gibi kuruyemişler; nar, incir, şeftali gibi meyveler ve burada adını sayamadığımız daha pek çok yiyecek ve içecek söz konusu hikâyede yer almaktadır. Hikâyede yer alan yiyecek ve içeceklere dair bazı örnekleri şöyle stralayabiliriz:

“... giderdi ve geminüñ içinde hod nafaḳāta nihāyet yog̉dı. Ḩānegī ḥelvā gibi bişmiş selvā gibi ve şeker börek gibi ve yağlı çörek gibi ve pür-șaḩanlar tavuk etleri ve pür-meşrebelerle şeker şerbetleri ve țolu destilerle āblar çün cüllāblar ki duhter içün ḩālesi virmişdi. Şeybū-y1 şirīn-kār ol nicmetden acıḳdukç̧a iftār iderdi ve șuṣadukç̧a ol şerbetlerden içerdi ve Hudā'ya hamd idüp ol duhter-i nīk-ahterüñ ay gibi cemālin temāşa eylerdi... (281-282)"

“... Balıḳçınuñ dört ḳuzgun gibi siyāh ḳızları var idi. Dördi dahı Reşīde'ye 'āşık olmışlardı ve her biri Reşide'yi benimseyüp cānları gibi țutup balığla besler idi. Zirā ol şehrüñ ekșer halḳı balık yirler idi ve etmekleri șūret țarısından idi ve yag̉ları șıg̀ır yag̀ıdı. Bunlardan gayrı nesne yoğıdı... (286)"

"Piste vü bādām u mevīz ü enār ve encīr ve bunlara beñzer nesneler getürdiler. Her ne varsa huşsk ter mivelerden bunlaruñ öñlerine dökdiler. Muhtār'la Kāạī 'acebe ḳaldılar. Derḥāl yine gitdiler. Bir dürlü ḳoyun getürdiler ve eyitdiler: Siz bog̉azlañ diyü işāret itdiler. Muhtār țurı gelüp besmele ile ve hamd ile bogazladı ve derisin yüzdi. Pāk itdi. Anlar dahı götürüp mațbaha iletdiler. Çün bişürüp yine bunlaruñ öñlerine getürdiler. Bunlar dahı yidiler... (499-500)"

\section{Ziyafet Verme}

Hikâyede yemekli ve içkili olarak verilen ziyafetlerin farklı amaçlar için kullanıldığı görülür. Savaşta kazanılan zaferin ardından zaferi kutlamak için, şehre gelen misafiri ağırlamak için, yaralanan bir kahramanın iyileşip sağlığına kavuştuğu için (Ciğa, 2018: 853-854) veya tuzağa düşürülmek istenen kişileri davet etmek için (Ciğa, 2018: 634) ziyafetler verilir. Bu ziyafetlerde şehirler, saraylar ve sofralarda yer alan tabaklar, kadehler türlü türlü süslerle ve değerli taşlarla süslenir; sınırsız yiyecek ve içecek ikram edilir; hānendeler/ mutribler tarafından farklı sâzlarla birbirinden güzel mûsikîler icrâ edilir, rakkâslar raksa girer ve çeşitli oyunlar sergileyen bü'l'aceb lu'bet-bâzlar bulunur:

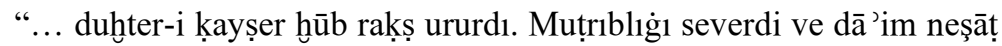
u țarab gösterürdi ve beşāşeti yüzinde zāāirdi. Çār-pāre bir rebāb eline alup çalmag̉a tạalib idi. Ol dahı̆ Şeybū ile hem-sāz ve hem-āvāz olup șoḥbet iderler idi ve gāh çār-pāre eline alup Şeybū ile dest-efşān-1 tậvus gibi cevelān iderdi ve gāh rebāb eline alup Şeybū ile yardah olur, terāne ırlardı. Egerçi țal' atı telbisle siyāh olmışdı ammā melāḥatı ve țarāveti ve nezāketi yirinde idi. Anı kim ta '⿳亠丷ir ider ve gāh gāh ol duhter-i ḳayṣer şāh-1 gīsū-yı siyāhın tā kemergāhına șalıvirüp raḳsa girür idi ve țāvus-1 ḳudsī gibi cevelān iderdi. Şeybū-yı fitne-engīz dahı eş ār-1 dil-āvīz oḳuyup țanbūre çalardı ve bir șoḥbet eylediler ki 
zengiler gaşy olup kendülerinden gitdiler ve anlaruñ üzerlerine sīm ü zer ü dürer-i gurer nisāar eylediler ki vașf itmek olmaz... (374-375)"

Şeybû çoğu zaman düşman tarafindan verilen ziyafetleri firsata çevirir. Ziyafet sırasında kılık değiştirip mutrib veya aşçı şekline bürünen Şeybû, yemeklere veya içeceklere bayıltıcı ilaç dökerek oradakileri bayıltır:

“...Çün Şeybū mațbaha varup aşına meşḡūl oldı. Cümle eț imeyi bişürüp hāāżır müḥeyyā itdi ve içine zehr katdı ve ḳayṣer ḳızına dārū-yı hūş-ber virdi ki şarāba ķatup zengīlere içüre ve kendülerinden geçüre. Çün Ceymuñ buyurdı.Bezmi reng-ā-reng mūcişlerle zeyn itdiler ve nuḳl bezdiler ve miyāne-i meclise bir ḩavż misālinde bir billūrīn bādiye getürüp ḳodılar ve anı erg்uvānī şarābla țoldurdılar. Ol duhter-i sīmin-sā' id bir zerrīn kadeh eline alup ortaya girdi. Ol şarāb-1 la' lfāmdan cāmı pür idüp Ceymūn şāha șundı. Çün Ceymūn alup nūş ḳıldı ve zamāne gușșasısı ferāmūş itdi ve 'işrete meşgūū oldılar. Elhâaș1l-1 kelām içerek nīm-mest oldılar. Bu mestlik içinde sāḳi-i sīmīnsāḳ furșat düşürüp dārū-yı hūş-beri bādiyeiçine șaldı ve ḳadehi pür idüp devr itdürdi. Henüz Ceymūn'a nevbet gelmedin yüz yigirmi zengī nūş idüp bī-hūş olup mürde gibi düşdiler... (438-439)"

\section{Armağan Verme/ Saçı Saçma}

Hikâyedeki hükümdarlar olağanüstü derecede zengin ve cömerttirler. Sayısız mücevher, altın ve gümüş dolu keseler, tabaklar dolusu inciler, çeşit çeşit kumaşlar, hil'atler hazinelerinin sadece küçük bir bölümünü oluşturur. Sevdiklerine, güvendikleri güçlü kahramanlara (Ciğa, 2018: 229-230; 738) gelin veya damat olarak gördükleri kişilere, kendi hizmetlerini görenlere ve halka zengin fakir, genç yaşlı ayrımı yapmadan bolca ikramda ve ihsanda bulunurlar. Bu ihsanlar ve ikramlar, yüzlerce kişiden oluşan ay yüzlü, badem gözlü cariyeler veya gılmanlar tarafindan sunulur. Hükümdarlar tarafindan verilen armağanlar deve veya katır sırtına yüklenecekse bu hayvanların eyerleri altından olur. Kahramanlar, kendi üzerlerine nisâr edilen altın ve gümüşe batarak görünmez hale gelirler:

“... Nice elli nefer miḳdārı mutrib-i hūb-elhānlar ki her biri sāzda ve āvāzda mümtāz-1 rūzgārdur ve cevāhirle ārāste bir tabla yüz ġulām-1 serv-bālā ve yigirmi kenīzek-i māh-liḳā ve bir taḩt-1 zerrīn ve yevāḳitle ve cevāhirle pīāste ki cihān pādişāhlarınuñ anuñ gibi bir

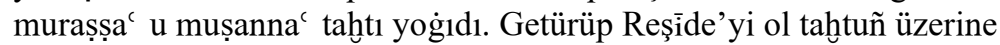
geçürdiler. Nice ay yüzlüler ve yay gözlü cāriyeler ve ellerinde birer zerrīn țabak la'l ile ve cevāhirle pür ve ba żısınuñ içi șāfïdür. Gelüp Reşīde-i māh-ruhsāra nișār itdiler ve şol ḳadar șaçu șaçdılar ki Reşīde görinmez old1... (299)"

Kahramanlar, gittikleri şehirlerin hükümdarlarına bazen hediyeler verir veya üzerlerine cevher, yakut gibi değerli taşlar saçar. Bu durum, şahın muhatap olduğu şahsın ne derece değerli ve kudret sahibi biri olduğunu göstermesi bakımından önemlidir.

“... Şāh buyurdı: Bir cāme-i şerīf ve yüz gulām ve yüz lațīf yüzi bedr ay kenīzek ve yüz bedevī at virdiler. Reşīde ol nazịif libāslardan giyüp 
Özkan CİĞA - Elements Of Social Life In Kıssa-i Seyyid Cüneyd ve Reşîde-i

Arab

ve atına süvār oldı ve serāyına gelüp ol dīvler vilāyetinden alup geldügi lac ldan ve yāḳūtdan ve zümürrüdden ve gayrıdan bir țabaḳı pür itdi. Çün eline alup sulțān ḩiżmetine geldi. Hezār gūne edeble ol țabaḳdaki cevāhir şāhuñ üzerine nișār itdi. Cümle halāyık anı görüp müte' accib kaldılar ve birbirine eyitdiler ki bu cevherlerüñ her birisi ol sulțān virdüginden ziyādedür. Ol dāneleri cem` idüp sulțānuñ öñine dökdiler. Çün pādişāh ol cevherlere nigāh itdi, müteḥayyir ḳaldı... (403-404)"

Geniş bir coğrafyada gelişen olaylar ve bu coğrafyaya giden kahramanlar bazen farklı kültüre sahip topluluklarla karşılaşabilir. Hikâyede maymunlar cezîresine düşen Kâdî ile Muhtâr altın ve gümüş yerine onlara türlü türlü yiyecekler ikram edilir ve onların yorgunluğunu almak için elleri ve ayakları badem yağı ile ovulur. (Ciğa, 2018: 499-500) Aynı şekilde düvâl-pâyların bineği olarak kapıya bağlanan Kâdî ile Sa'd-1 Mısrî üzerine altın ve gümüş yerine kuru ve yaş yemişler nisâr edilir:

“... K়ạḍịyle Sa'd-1 Mıșrī naz̧ar itdiler, gördiler ki evlerine 'aded yoḳdur. Ammā cümlesi ḩār u hāşşākdan dürülmiş örme sepede beñzer țār evler. Yine niçe sūḳaḳlar evleri içleri huş̧ ter mīveler țolmışdı ve cā-be-cā balıḳ etleri dahı çog̉dı. Kăḍ̂ị’yle Sac d'ı ev ḳapusına iledüp baġladılar ve kendüleri dahı üzerlerinden indiler. Düvāl-pāylerüñ 'avretleri ve og̉lancukları ol ḳuru yaş yimişden getürüp başları üzre nișār itdiler. Çün şādlıḳlar idüp na' ralar urdılar ve balıḳ etin yumurda ile bişürüp öñlerine getürdiler ve ne țurursız yiñ didiler tā ki kuvvetüñüz ziyāde olup bizi getürmeklik size āsān ola... (507)"

Hikâyede bağlama göre bazen üzülen bazen gülen Hârûn Reşîd, Ebû Hafs'ın anlatımından memnûn kaldığı durumlarda Ebû Hafs'ın üzerine binlerce altın, mücevher ve dînâr nisâr eder. Bazen Ebû Hafs'ın dâmenini altınla doldurur. Böylece okura okuduğu hikâyenin ne derece güzel ve nasihat içerikli bir hikâye olduğu hatırlatılır:

“... Hualífe eyitdi: Aḥsent ey Ebū Ḥaf̣s sözüñ dādını virdüñ didi. Her kimesne ki bu ḳıșsa-i nașihhat-h̆ıșsayı yahşı oḳusa ve te'emmül eylese aña ziyāde fevā’id hāṣıl olur, didi ve dahı 'ömr lezzetini bula ve ‘ömr ve dünyā çün hạ̄lini bile, didi. Andan üstine hezār dīnār nișār itdi... (769)"

\section{Eş Seçimi, Evlenme ve Boşanma}

Hikâyede kimi zaman karşımıza çıkan eş seçme veya evlenme, boşanma ile neticelenen ilişkiler, çoğu zaman İslâm inancına ve gelenek göreneğimize ters düşmeyen bir yapı arz eder (Atar, 2007: 112-117). Ancak bazen cinler, perîler veya başka yaratıklar tarafindan kaçırılan kahramanlar evlendirilmek istenince âdetlerine göre ya dügün günü ertelenir ya da damatlara en az gelin kadar önem gösterilir.

Hikâyede Hz. Abbâs, daha önce Seyyid Üseyd'e vermemek için eşinden boşanma üzerine and içtiği kenîzeki Seyyid Üseyd'e vermeye karar verir. Bunun üzerine kenîzeki azad eder ve boşanmaya gerek kalmaz. Daha 
sonra düğün hazırlıkları başlar. Seyyid Üseyd ile kenîzekin talihine bakılarak nikâhlarının uğurlu bir saatte yapılmasına dikkat edilir:

“... ey țabīb-i mu'teber müvecceh buyurduñuz ammā ne idem ki talāḳa and içmişemdür ki kenizeki Üseyd'e virmeyem. Hakīm eyitdi: Ey Hudāvendgār sevgend sehl ü āsāndur kenīzeki āzād eyle ba' de Üseyd'e nām-zād ḳıl, tā talāḳ vāḳı' olmaya didi. 'Abbās'a bu cevāb șavāb geldi ve hemān-dem kenīzeki āz̄ād idüp Üseyd'e nām-zād ḳıldı ve bir nice günden șoñra esbāb ve cihāzı müheyyā itdiler. 'Abbās'uñ

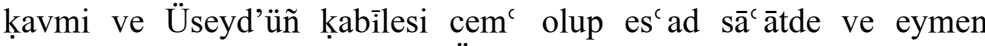
evḳătde ol duhter-i nīk-ahterini Üseyd-i servere nikāḥ eyleyüp virdiler ve çün 'āşı̣ ma'şūḳa vāṣıl olıcak ževḳ-i dü-cihānī ve şevḳ-i cāvidānī hậ̣sıl old1... (172-173)"

Reşîde'nin babası olan Amr'ın yine Reşîde'nin perî olan annesi Zehrâ-y1 Perî'nin evlilikleri İslâm inancına göre yapılır (Ciğa, 2018: 198). Perîler tarafından kaçırılan Reşîde'yi perîler, kendi oğullarına gelin olarak düşündükleri zaman bayramları olduğundan Reşîde'ye altı ay mühlet verirler:

“... Ey duhter-i nīk-ahter dilerin ki seni bu sā' at og̉luma 'arūs ideyin. Ammā şimdi altı ay müddet ü mühlet virdüm ki bizüm bir 'ỉümüz vardur. Ol 'ìde va'demüz olsun. 'İdümüz idelüm, andan șoñra dügünümüz idelüm... (304)"

Hikâyenin bir başka yerinde ise Reşîde evliliği bir ay erteletmek için dügünün iki bayram arasında olursa daha hayırlı olacağını dile getirir. $\mathrm{Bu}$ inanış, günümüzdeki iki bayram arası yapılacak düğünün hayırlı olmayacağı inanışının tersine bir durum olması açısından dikkat çekicidir:

“... Ammā perīler pādişāhınuñ erkān-1 devletine ve $\bar{a}^{c}$ yān-1 hażretine eyitdi: Siz hāakimsiz ammā peder-i 'azīzümden işitdüm ki ve 'uḳalā

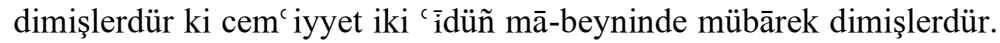
Şimdi garīb-nüvāzlık eyleñ ve derin ki ol bir ayda idesiz. Anlar eyitdiler: Ey duhter-i māh-rū ve ey ahter-i siyāh-mū biz saña muvāfaḳat itmek içün āsāndur. Ammā zamāne bize müdāvemet göstermez ve cümle dīv peri içine senüñ țal'atuñ lețāfeti āvāzesi gitmişdür ve yaḳındur ki senüñ ' aşkụun sebebiyle cihān ḩarāba vara sen 'arūs olıcak halḳ-1 cihān senden nevmīz olup sükūn bulurlar. Ammā senüñ murādınca olalum kendümüze cebr idüp bir ay dahı șabr idelüm, elümüzden ne gelür...(379-380)"

Devler, Reşîde'nin nikâhını kıymak için şeyhleri olan şeytanın gelmesini beklerler (Ciga, 2018: 385) Kâdî ise Reşîde ile Seyyid Cüneyd'in nikâhını İslâm inancına göre kıyar:

“... Kạḍ̂i çün Reşīde-i 'Arab’1 āhiret ḳız ḳarındaşlıg̉ına ḳabūl itdi ve eyitdi: Ey Seyyid sizüñ nikāḥuñuzı iẓhār iderdüm ki naẓardan mu'āḩez olmayasız çün bu cengden fārig olavuz, andan cem'iyyet idelüm, didi. Derḥāl Kậ̣̂i Reşīde'yle Seyyid'e 'aḳd-1 nikāḥ itdi...(817-818)" 
Özkan CİĞA - Elements Of Social Life In Kıssa-i Seyyid Cüneyd ve Reşîde-i

Arab

Hikâyede eş seçimi konusunda bazen farklı düşünceler dile getirilir. Daha önce güreş tutma konusunda zikredilen Reşîde'nin eş seçimi için pek çok kişi ile güreş tutması hikâyenin sonraki kısımlarında da karşımıza çıkar. Reşîde'yi kendi oğluna almak isteyen Sultân Mansûr'a Reşîde'nin bir teklifi olur. Gücüne güvendiği pehlivânları güreş meydanına getirmesini ve onları yendikten sonra kendi oğlunu da getirmesini ister. Sultân Mansûr'un oğlunu tek eliyle yenebileceğini söyleyen Reşîde, oğlunun kazanması durumunda ancak eş olabileceğini ifade eder. Ayrıca evliliğin güç yönünden denklik olursa olabileceğini dile getirir:

“... Reşīide eyitdi: Senüñ leşkerüñden ne ḳadar güzīde pehlevānuñ vardur kim ceng güninde ḍarbda ve harbda tamām be-nām olalar. Manșūr eyitdi: Yetmiş nefer güzīn pehlevān-1 nāmdārum vardur. Reşīde eyitdi: Buyur ol yetmiş nefer pehlevānı getürsünler dahı emr eyle benüm ile güreş țutsunlar. Ben ol yetmiş pehlevānı bașdug̉umdan șoñra og̉luñı andan meydāna getür. Anı dahı bașam ammā şol şarțla kim bir elümi bag̀lañ ve bir elümle bașarsam hoş didi. Eger og̉luñ beni bașarsa ben anuñ ' avreti olmag̉a rāżı olam. Nice 'avret arslan gibi ola ve er dilki gibi ola. Çün halvet olıcak ol 'avretden niçe murād ala ve hâașıl eyleye. Āhir bu işde endīşe eyle. Manșūr Reşide'nüñ sözinden 'acebe kald1...(639)"

Siyahlar kalesine giden Muhtâr ile Kâdî, kaleyi ele geçirmek için bir plan yaparlar. Muhtâr, şahın kızına tâlip olduğunu söyler. Bunun üzerine sevinen şahın kızı hemen onun yüzünü gözünü öper ve üzerine değerli taşlar saçar. Bu durum damada en az gelin kadar değer atfedildiğini gösterir:

“... Duhter-i şāh bu sözi işidicek be-gāāyet dil-şād olup Muhtār'a 'āşık oldı ve anası dahı sevinüp Muhtār'ı begendiler ve anası feraḥından segirdüp Muhtār'uñ yüzin ve gözin öpdi ve az ḳaldı ki Muhtār ol karınuñ bed-rāyihạāsından lā-yu' ḳāl olup düşeyazdı ve ammā bir ay mașlaḥat șabr eyledi ve hiç söz söylemedi. Çün bir pāre ilerü gitdiler bì-ḥad cevāhir ü zergetürdiler dahı Muhtār'uñ ayaġına zer ve başına cevāhir nis̄ār itdiler ve neşāṭ u țarab dahı gösterdiler ve Muhtār dā ’imā gülerdi ve söz söylemezdi... (349)"

\section{Tuz Ekmek Hakkı}

Türkçe Sözlükte "Birinin ekmek yedirip iyilik ettiği kimse üzerindeki manevi hakk1 (2011: 2395)." olarak ifade edilen "tuz ekmek hakkı" deyiminin Türk kültüründe önemli bir yerinin olduğunu söyleyebiliriz. Gerek tarihî ve edebî eserlerde gerek halk edebiyatının çeşitli eserlerinde bu deyime rastlamak mümkündür (Samsakç1, 2012: 181-199). Kıssa-i Seyyid Cüneyd ve Reşîde-i Arab'da bu deyim nân u nemek hakkı veya hukûk-ı nân u nemek şeklinde geçmektedir. Hikâyede anlamına uygun bir şekilde kullanılan bu deyim kahramanlar tarafından yer yer dile getirilir. Tuz ekmek hakkı sayesinde bazen büyük bir savaşın veya kavganın eşiğinden dönülür:

“... Aylan eyitdi: Benüm senüñ atañla meveddetümüz ve muhabbetümüz vardı. Mā-beynümüzde haylī ḥuḳūḳ-1 nān u nemek 
varduginn murādumuz saña dimekdür. Ḥayfdur ki ben senüñle seyf çıkarup ceng idem didi... (254)"

“... Reşīide kendüye eyitdi: Ben ol pādiş̧āh-1 siyāhuñ nān u nemegin hakkḳını gözlemedügümçün Huz̄ā beni bu belālara giriftār itdi ve bu belālara ve bu zecrlere ve bu rüsvāylıklara sebeb ḳızları ḳanlarınuñ ecirleridür kim old1... (299)"

\section{9. Ă̆ıt Yakma / Sağu Sağma}

Tarama sözlüğünde "Ölünün iyiliklerini acıyla sayıp dökmek (2009: 3246-3249)." şeklinde yer alan "sağu sağ-" deyimi günümüzde "ağıt yak-/ yas tut-/ mâtem" ifadelerinin eş anlamlısı olarak kullanılır. Geçmişten süregelen ve bir gelenek olarak günümüz toplumunda da devam eden yas tut-/ ağıt yak-/ sağu sağ-/ mâtem durumu edebî eserlerde bazen bir tür olarak karşımıza çıkar (İsen, 1994).

Klssa-i Seyyid Cüneyd ve Reşîde-i Arab'da mâtem sırasında ölünün yakını onun ardından firkat ocağında sac üzerine geçüp saç yolar, hasret tırnağıyla yüzünü yırtıp ağlar, dert ateşiyle ciğerini dağlar, yakasın çâk eder, başına toprak saçar, bindiği atın kuyruğunu keser, karalar giyip mātem-zede olur. Halk, taziyeye gelir ve ölünün yakınından başsağlığı diler:

“...Reşīde atasınuñ ve birāderinüñ ve 'ammüsinüñ mevtlerinden ve fevtlerinden işidüp ḩaberdār oldı. Feryād idüp zāra başladı ve ḳabā’ill-i 'Arab emīrleri ve Beni-Şeybān dilïrleri Reşīide-i 'Arab'a ' azāya gelüp eyitdiler: Siz bāḳi oluñ nice idelüm böyle imiş emr-i Hudā-yı bì-çūn innā li'llāh ve innā ileyhi rāci' $\bar{u} n$ ve cehdi aña eylemek gerekdür kim muḥkem rezm idüp anlaruñ ḳanları yirine bunlaruñ cānların alavuz... (181)"

Hikâyede işi sağu sağmak olan mûyeger avretler bulunur. Bunlar, ses yönünden çok iyi ve farklı enstürmanlar çalmayı bilen kişilerdir. Onlar ağıt yakmaya başlayınca mâtem yerinde bulunanlar zâr zâr ağlayarak kendinden geçer ve mûyegerle birlikte semâ'a girerler. Şeybû bazen k1lik değiştirip dostlarıyla öldürdükleri şahsın mûyegeri yani ağıt yakıcısı olur. Şeybû ve dostlarının mûyeger vasfiyla gittikleri yerlere sâz âletlerini de yanlarında götürmeleri o dönemde mâtem tutma tarzının günümüzdekinden biraz daha farklı olduğunu gösterir:

“... Şeybū ile Muhtār kendülerini mūyeger 'avretler gibi düzünüp kayșer şehrine bād-1 șarșar gibi gitmişleridi ve nice müddet-i medidden șoñra şehre yetmişleridi. Şehr ve harem-i ḳayṣere girüp șag̉u șagarlarıdı. Şöyle ki diñlenürler dahı zārī zārī ag̉lardı ve Hārūnu'r-reşīd halīfe ḳahḳahaya düşdi ve eyitdi: Söyle ey muhaddis Şeybū ile Muhtār ol 'avretlerle bilelüm ne kār eylediler? Ebū Ḥaf̣s-1 Kūfì eyitdi: Kayșer ḩَāher-zādesiyle Heraḳl ta'ziyesine oturmışdı. Kayṣerüñ halḳı Şeybū'yı söylemişlerdi ve Şeybū dahı bir def șatun almışdı dahı Muhtār eline virüp yardah idinmişdi. Kendüsini sāzendelik eyler idi. Rāvī şöyle rivāyet ider ki Şeybū-yı ḥile-bāz sāzda ve āvāzda bīinazīrleridi ve maḳāmātda 'adīmü'l-meșel idi. Şöyle ki istimā' idenler bi $\bar{i}$-ihtiyār semā' a girüp ' $\bar{a}$ lem-i vecde varurlardı ve 
Özkan CİĞA - Elements Of Social Life In Kıssa-i Seyyid Cüneyd ve Reşîde-i

Arab

Muhtār daḩı hun̄b-nefesdi ammā libās-1 hayāyla mülebbes idi. O sebebden mūyegerlige heves itmezdi... (260-261)"

\section{Mektup Yazma}

Birini bir konu hakkında bilgilendirme veya birine haber gönderme amacıyla yazılan mektupların hikâyede de aynı amaç doğrultusunda yazıldığı görülür. Hikâyede kimi zaman kahramanların, yıllarca göremediği sevdiklerine mektup yazdıklarına da şahit olunur. Ayrıca mektupla beraber pek çok eşya gönderilir:

“... Bir mu'temed kimesne dilerüz ki bu māllarumuzı ve ișḳāllerümüzi anuñ eline virevüz. Alup tā Mekke'ye ilete ve Mekke'nüñ sādātına teslīm ide ve anlar daḩı fuḳarāya harc eyleyeler ve hem bizüm aḳribāmuza bizden hayır haber vireler tā bizüm ṣị̣hatumuz ḩaberinden mesrūru'l-ḥāl u maḥbūru'l-bāl olalar ve pādişāh-1 şehr eyitdi: Ey dil-āver-i civānlar göñlüñüzi hoş țutuñ ki benüm og̉lum bendeñüz bu yıl hacca gider. Ol hižmeti edā itsün. Muhtār-1 dil-āver çün bu ḩaberi işitdi, şād oldı ve cümle māl vardur ki Cemşīd'üñ kal' asından çıḳarmışdı. Pādişāhuñ og̉lına virdi ve bir mektūb dahıı getürüp eline virüp andan fārig̀ oldılar... (368)"

Aynı şekilde hikâyede, etrafi düşmanlarla çevrilmiş bir şehirden bahsedilir. Bu şehrin dışında kalan Muhtâr şehrin dışında olan haberleri her fırsatta şehrin içine ok vasıtasıyla bildirir. Bu haberlere karşılık şehrin padişahı vezirine bir mektup yazması için emreder. Mektubu padişahın veziri ibârât-ı fesahatla yazarak mühürler ve mektubu götürmek üzere bir bayana teslim eder. Bayan mektubu içine gizleyebileceği bir ayakkabı diktirir ve mektubu Muhtâr'a iletmek üzere yola çıkar (Ciğa, 2018: 776-777) Hikâyede mektup bazen Şeybû'nun bir hîle aracı olarak işlev görür. Şeybû başka birinin ağzından yazdığı mektupla haberci şekline girerek düşmanını tuzağa düşürmeye çalışır:

“... Derḥāl oturdı, Kāhūr'uñ ḳavlinden bir nāme yazdı aña ki ben fülān gün Fercān şehrine vardum.Fercān şāhı Reşīe-i ' Arab'1 ve dahı̀ Hamza'nuñ kavmini giriftār itmiş, saña getüri yorur, tā ki Cüneyd'i atañ ḳanı içün depeleyesin ve Reşīe-i 'Arab'1 andan og̉luña virem. Sen otur tā ki ben varam. Çün mektūbı tamām idüp derḥāl kendüzini bir siyāh eyledi ve eline bir dāne 'așā alup andan revāne oldı. Çün leşkergāhagirüp Kerās'uñ çün ḩargāh-1 bārgāhına varup eyitdi: Ben Kāhūr'uñ ḳāṣıdıyam, didi. Anı Kerās'uñ öñine iletdiler. Şeybū çün içerüye girdi ve hizmeti yirine getürdi. Mektūbı çün vezīiüñ eline virdi... (797)"

\section{Fala Bakma/ Talih Tutma}

Hikâyede kimi zaman karşımıza çıkan fala bakma/ talih tutma işinde "ilm-i nücûm"dan, "fenn-i üsturlâb"dan, "zeyc-i Rûmî'den" ve "reml tahtasın"dan faydalanılır. Fala bakan kişi ise pek çok ilmi bilen ve ilm-i nücûmdan ve fenn-i üsturlâbdan anlayan müneccim veya kâhindir. Bazen 
doğan çocuğun bazen de gelin damad adaylarının talihine bakılır ve evliliğin olup olamayacağına karar verilir. Evlilik olacaksa en uğurlu anın ne zaman olduğuna bakılır. Örneğin hikâyede Seyyid Üseyd ile kenîzekin talihine bakılır ve gelecekte olması muhtemel şeyler hakkında kendilerine bilgi verilir (Ciğa, 2018: 171-172). Şeybû ise kılık değiştirerek kimi zaman "ilm-i nücûmdan ve fenn-i üsturlâbdan" anlayan müneccim veya kâhin olur. $\mathrm{Bu}$ k1lıkla gittiği yerlerde çeşitli bilgiler edinmeye çalışır.

“... Şeybū be-ḡāyet müdrik şahșdı. İdrāk itdi ki Reşīde’yi yegāne dīv beyābāna bıraḳmışdur. Kendü kendü ile fikr itdükden șoñra reml tahtasını öñine alup nokța düşdi. Öte cizdi ve beri cizdi hānlara naz̧ar itdi ve gözin oynatdı ve țudaġın ḳımıldatdı. Başın șalup bunlara eyitdi: Ṭālic in țutdum gördüm dīvden ayrılmış beyābānda ser-gerdāndur. Bunlar eyitdi: Ey ḥakīm bu arada rāst beyān itdüñ. Hem eyledür diyüp Şeybū'ya hil' at u ni'met virüp 'izzet ü hürmet itdiler çün Şeybū Reşīe hāāinden ḩaberdār oldı... (223)"

\section{Ad Verme}

Klssa-i Seyyid Cüneyd ve Reşîde-i Arab'da ad verme geleneğine de rastlanır. Hikâyede çocuğa verilecek olan ad, çocuğun yüz güzelliğine, talihine göre değişir. Bazen anne veya babası tarafından bazen de çocuğun talihine bakan ve pek çok ilimden haberdâr olan kişi tarafindan çocuğa ad verilir:

“... Üseyd-i serverüñ nutfe-i nazīifi duhter-i nīk-ahterüñ rahm-1 lațîfine düşdi bā-emr-i Șānic haml vāḳı oldı. Toḳuz ay ve toḳuz günden șoñra duhter-i nỉk-ahterden bir gün yüzlü oġlan doġdı ve ol ḥakīm-i hıredmend bu ferzendüñ țâli in țutdı. Be-ḡāyet ercmend görüp adını Cüneyd ḳodı... (173)"

“... Reşīde-i 'Arab'uñ dahı ḩaml müddetinüñ 'iddeti yetdi. Ol es' ad sā' atda ve eymen evkāâtda bir sehergāh nā-gāh Reşīde-i māh-liḳā vaż' 1 ḥaml itdi. Bir ăftāb țal'at og̉lan çün țulū' itdi. Şöyle ki çün cemālinüñ nūrı cihānı münevver kılldı.Adını çün 'Abdu'r-rahman ḳodılar ve dahı şāzlılḳlar itdiler. Mü'ellif-i kitāb eyidür ki Seyyid Cüneyd ol perrende atları ol günde șalıvirdi. Andan șoñra beş yıl ol makāmda mukīm oldı ki diyār-1 H'ārezm'de 'Abdu'r-rahman'dan șoñra Reşide-i māh-peykerden yine bir duhter-i nīk-āhter tọgdı. Adını Sāre kodılar çün Sāre beş yaşına girdi ve 'Abdu'r-raḥman altı yaşında idi... (896-897)"

\section{3. Çocuğun Dadıya Verilmesi ve Eğitimi}

Doğu toplumunda yaygın olarak görülen yeni doğan bir çocuğun belli bir yaşa gelene kadar dadıya/sütanneye verilme geleneği bu hikâyede de görülür. Hikâyede Cüneyd doğduktan sonra dadıya verilir ve yedi yaşına kadar dadısı tarafından emzirilir. Cüneyd'in eğitimine de ayrı bir önem gösterilerek genç yaşta hemen her ilimden haberdâr olması sağlanır. Yine genç yaşta ok atmayı, kılıç sallamayı, ata binmeyi, güreş tutmayı ve nihayetinde ava çıkmayı ögrenerek hayata hazırlanır: 
Özkan CİĞA - Elements Of Social Life In Kıssa-i Seyyid Cüneyd ve Reşîde-i Arab

“... Be-gāāyet ercmend görüp adını Cüneyd kodı. Atası Üseyd’üñ re'yiyle dāyeye virdiler ve tā yedi yaşına degin dāyesi emzirdi ve ba' de-zān mektebe virdiler, tā kitāb oḳuyup 'ulūm u ādāb ögrendi ve çün Cüneyd on dört yaşınna irdi. Cemāli māh-1 tamām gibi tābende oldı ve her kim anı gördi āstānında añabende oldı ve kemāl-i nihāyete irüp tā hıredmend oldı ve makāl-i șeyh ü sāaba bend oldı ve cebhesinden ululuk envārı 'āleme işrāk itdi ve çehresinden bahādırlık āsāarı birle meşhūr-1 āfāk oldı ve andan șoñra Cüneyd'üñ zūrı ziyāde olup silāḥşorluga başladı ve anı dahı tekmīl idüp esb-i tāzīlere süvār olup şikār hevesin itdi ve çün on beş yaşına irdi, hịç kimse anuñ kemānı kirişin yirinden ḳımıldadamaz idi ve çün on altı yaşına irdi şöyle oldı ki ol rūzgāruñ süvārları ve merdān-1 nāmdārları mecālisinde Cüneyd'üñ merdāneligin ferzāneligin ve sahāasın 'ațāsın ve bežlin 'adlin ḍarb-1 mesel eyidürlerdi. Kerrātıla tenhā bir iki yüzmerd-i dil-āver ile ve mübāriz ile neberd içinde berāberlik itmiş̧i. Belki ziyāde gelürdi ve dahı küş̧tgīllikde şöyle oldı ki hịç kimesne püştin yire getüremezdi. Hुattā on merd-imübāriz er bir ugưurdan hamle iderlerdi ve her birin bir lu'bla bașardı ve dahı hịç kimse pençesin pịç idemezdi. İttifākāā bir gün esbe süvār ve 'azm-1 şikār itdi... (173-174)"

\section{4. Çeşitli Meslekler}

Sosyal hayatta, toplumun ihtiyacı sonucu ortaya çıkan meslekler hemen her dönemde değişen şartlara göre çeşitli isim ve icraatlarla varlığını sürdürmektedir. Tarihin eski çağlarından beri süregelen mesleklere ve bazen bu mesleklerin incelikleri hakkında detaylı bilgilere tezkirelerde olduğu gibi birtakım yazılı eserlerde de rastlamak mümkündür. Bu yazılı eserlerden biri de Kıssa-i Seyyid Cüneyd ve Reşîde-i Arab'dır. Hikâyede bir kısmı günümüzde farklı isimlerle devam eden çeşitli meslek isimlerine ve erbâblarına rastlanır. Ancak meslekler hakkında detaylı bilgiye yer verilmez. Bazen sadece meslek isimleri verilir.

Bir meslek olarak icra edilen ve ticaretle uğraşan kişi anlamına gelen "bâzergân/ tüccar" hikâyede sıkça karşımıza çıkar. Kahramanlar ya tüccar kılığına girerek seyahat eder ya da yolda gördükleri tüccarların kervanına katılarak gitmek istedikleri yere varmaya çalışırlar. Hikâyede yer alan tüccarların ise büyük çoğunluğunu Yahûdîler çok az kısmını ise Müslümanlar oluşturur:

“... Ol tozuñ içinden bir kārvān gördiler. Bir ulu bāzergān biñ țavārla gelüp bu harābeye ḳondılar. Cüneyd'le K̦ạḍi gusușa vü gamdan āzād olup şād hurrem oldılar. H`̌āce-i bāzergān bunlara naẓar itdi, hāṭtırlarını pejmān gördi. Ḩăț̣ların ele alup ya' nī helvā vü āb nān virdi

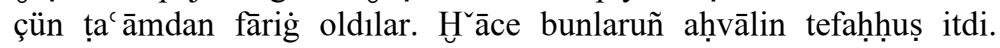
Gördi, Cüneyd'i bir nev-civān-1 zībā-ḩadd bālā-kadd cesīm, 'azịim ve Kăậī'ye dahı nazar itdi. Gördi bir civān-1 nev-hutṭt kelimātı müretteb ve bāzergān eyitdi: Ne yirdensiz ve ne yirden gelürsiz ve ne yire gidersiz? Bunlar dahı h้⿳ācenüñ su'āline cevābvirdiler ki biz bāzergānlar idük bir müşkil vāḳı aya vāḳı olduḳ. Hู`āce eyitdi: Sizde 'alāmet-i ticāret yoḳdur ancaḳ diyicek bunlar daḩı ağlamag̉a başladılar. Gurbet çekmemiş tāze civānlar idi ve şol ḳadar ag̉ladılar ki hु āceye dahı riḳkat gelüp bunlara şefkat ve merḥamet gösterdi ve 
göñüllerin ele alup bizüm ile bile oluñ didi. Ol gice anda rāḥat olup yarındası seherden bile rı̣̣let itdiler ve Kạḍ̂i anlara evḳāt-ı hamsede ezān oḳuyup namāzı ḳılıvirdi. Hūū Kưư̄ān oḳurdı. Anlar dahı Kạḍị'nüñ murādınca deprenüp mürīd oldılar ve Cüneyd dahı konmaḳda ve göçmekde ve binmekde ve inmekde anlara mu'āvenet iderdi. Şöyle ki dört beş kişi ḳaldurmadug̉ı yüki bir el ile ḳaldurup țavar üstine kordı... (228)"

Hikâyede balıkçılık mesleğinin de yer aldığı görülür. Hikâyenin bir bölümünde Reşîde ile karşılaşan balıkçı onu erkek sanarak kendi evine götürür, kızlarından birini ona vermek ister ve ona ikramlarda bulunur. Balıkçının Reşîde ile arasında geçen diyaloğuna bakılınca o dönemin sosyal hayatı ve balıkçılık mesleği ile ilgili çeşitli bilgilere varmak mümkündür:

“... benüm bir ' avretüm vardur ve dört siyāh-çerde duhterüm vardur. Her birinüñ cemāli ayuñ on dördi gibi tābendedür ki Zühre aña cāriye ve Mirrih aña bendedür ve ol kılaruñ kankıısın dilerseñ anı saña vireyin ve benüm güyegüm ol ḳatumuzda 'izzet hürmet bul. Senüñle her gün piyāde gelelüm, deryāda balık țutalum ve şehre iledüp șatalum. Akç̧asın avucu içine virüp yiyelüm içelüm, hoş geçelüm, Ḩālıḳ'a şükr idelüm. Duhter bī-çāre n'ola didi. Turdılar yüklerin yükleyüp şehrden yaña revāne oldılar ve gice vaḳti irdi, şehre geç girdiler ve Reşīde şehri gördi bir mu' az̧zam şehr içi pür-galaba ne Şām'a beñzer ve ne Hialeb'e... (218)"

“... Öñine șūret țarısı etmekle balıḳ kodılar, zīrā gayrı nesneye kāāir degüller idi gāayet fakīirler idi. Ol şehrde egerçi dervīş çok idi ammā bunlara beñzer yoġdı. Balıḳcılıḳla dirilürlerdi. Reşīde balıḳdan biraz

ifțār itdi ve Rabb'ine şükr-güzār old1... (219)"

Hikâyede, gemideki mürettabat anlamına gelen günümüzde tayfa olarak adlandırdığımız "mellâh"lara, eskiden hükümdarların kapı önünde bulunan "bevvâb"lara, yine hükümdarlar arasındaki iletişimi sağlayan ve mektup/ fermân/ haber ulaştıran "kâsıd"lara, zindanda hükümlüleri gözetim altında tutan "zindanbân/ bekçi”"lere, halkın çamaşırlarını yıkayan "câmeşûy/ kâzur"lara, yük taşıyan "hammâl"lara, hamamda görevli olarak yer alan ve günümüzde tellâk olarak isimlendirilen "dellâk"lara, yaralıları ve hastalıkları tedavî eden tabîb/ hakîm"lere, yine tedavi amaçlı hacamat yapan "haccâm/ haccâme"lere, surları veya çeşitli yapıları yıkan "külüng-zen"lere, taziye evlerinde ağıt yakan "mûyeger"lere, şark1 söyleyen "mutrib/ hânende"lere ve buna benzer pek çok meslek isimlerine rastlamaktayız:

“... Ey benüm hem-rāhum, ben ne kār eyleyem? Șan'at daḩı bilmezem ve sermāyem daḩı yoḳ tā anuñ ile șatu bāzār eyleyem. Eyitdi: Hูışt-zen ol ve yāhūu mellāḥ ol ve yāhuūd hammāl veyā irgaad ol, didi. 'Avretüm baña bu işleri ' arż eyledi. Benüm daḩı bu işlerden hammāllıg̉a meylüm ziyāde oldı ve yarındası șabāh oldı. Elüme bir ip alup bir çüvāl omuzuma artdum ve bāzārdan yaña müteveccih olup gitdüm...(573)"

“... gicelerde iplik egirüp gündüzlerde cāme-şūy olmışdur. Çok zaḥmet çekmişdür. Eger beni bu sā' at ten-dürüst göricek olursa yarın yine beni ḥammāllığa gönderür... (576)" 
Özkan CİĞA - Elements Of Social Life In Kıssa-i Seyyid Cüneyd ve Reşîde-i

Arab

“... zindānuñ kapusı açıldı. Cüneyd tạşa çıḳdı. Gördi zindānbānla kırḳ bekciler uyumışlar, ölü mișālinde yaturlar... (263)"

“...Nice elli nefer miḳdārı muțrib-i hūu-elhānlar ki her biri sāzda ve āvāzda... (298)"

“... bir haccāme 'avret getürdiler. Çoḳ dārū düzüp Reşide'nüñ cerāḥatlarına ḳodılar ve hāak ile ḳanıyla bulaşmış a żāāın yudılar ve şerbet virdiler... (298)"

“... Şöyle ki menāreden ol 'araba üzerine hezār țaş düşerse dahı altundaġılara mużırrat irişmezdi. Külüng-zenler ol 'arabanuñ altına girüp oturdılar. Ol 'arabayı güçile çeküp menāre dibine iletdiler. Külüng-zenler dahı menāreyi dibinden bozmag̉a başladılar... (616)"

“... Beni ḥammām içine koydılar. On nefs gulām-ı māh-peyker baña dellāklık eylediler... (585)"

\section{Kılık Kıyâfet}

Kıssa-i Seyyid Cüneyd ve Reşîde-i Arab'da kahramanların kılık kıyâfet ile ilgili tercihleri bize hikâyenin yazıldığı dönemdeki sosyal hayat hakkında ipucu verir. Hikâyede kahramanlar gece yolculuğuna çıkacaksa "şeb-revâne tonlar" giyer ve ona göre silâh alır. Kahramanlar güreş meydanına çıkacaksa "câme-i sahtiyân ve sahtiyân tuman" giyer, savaş meydanına çıkacaksa gereken silâhları yanına alarak zırhını giyer, başına "1şık/ miğfer" takar:

“... Şeb-revāne țonlar giyüp andan üstād Batur’a geldi. Eyitdi: Benüm ile bu gice sen hem-rāh ol ki cāzūlar içine varalum, didi. Ol daḩı yirinden țurdı, vardılar. Tìgiñ hamā’̀il ḳılup ikisi revāne oldılar tā cāzūiar içine girdiler... (743)"

“... Şeybū duhter-i ḳayṣere gulām libāsın giyürdi ve başına külāh geçürdi ve beline kemer bağladı ve kendü dahı kendüzini yüz elli yaşında bir pīr şekline kxoydı ve bir yeñi bol 'abā giydi ve bir büyük dülbend șarındı... (369)"

“... Temāşā iderken içinde bir zırh gördi. Pỉrāhen misāāinde her kim anı giydi hīç aña ḳılıç kār itmezdi. Ol zırhuñ șıkleti bir rațl miḳdārı var idi. Ol zırhda Behrām-1 Gūr adı yazılmışdı. Reşìde haț̣̂nı oḳudı. Hemān zırhı ḳaftan altına aldı... (385-386)"

Savaş meydanından dönen asker savaş teçhizâtlarını çıkarır ve gece oturup dinleneceği meclis kıyâfetlerini giyer:

“... Çün güneş țulundı iki 'askerden țabl-1 āsāyiş çalındı. İki leşker birbirinden bölindi kim öldi ve kim ölmedi bilindi. Üseyd'üñ mecrūḥ olduġından Medīne şehrine ve leşkerine ża' $f$ irüp Medīne’ye girdiler ve Reşìde leşkeri çadırlarına irdiler. Emīr-zādeler her biri silāḥ-1 rezmin çıkarup libās-1 bezmini giydiler... (185)"

Kimi zaman erkek k1lığına girip pek çok ülkeye seyahat eden Reşîde, yüzünü örtmek için "bürka/ dülbend' saçını saklamak için ise "hâdimâne libâslar" giyip bazen başına bir külâh takar:

“... bir mașlaḥat içün żarūrī țaşra çıḳmaḳ vāḳı` olsa idi yüzine bürḳac çeküp çıḳardı... (286)” 
“... bir vaḳt bir mașāfda bād Reşīde’nüñ bürḳa' ın güşāde ḳılmış idi ve cemāl-i cemīlin görüp 'āşıłk olmışdı... (295)”

Hikâyede gittiği diyârlarda farklı kültürlere tanıklık eden kahramanlar, kimi zaman sadece "avret yerleri" ve "dizleri" örtülü olan insanlarla kaşılaşırlar. Vücudlarındaki örtülü yer ise yalnız koyun derisiyle kaplıdır. Bu durum, hikâyedeki olayların merkezinde yer alan toplulukların arasındaki gelişmişlik düzeyini göstermesi bakımından önemlidir. Bir toplum sosyal ihtiyaçlarını en iyi şekilde karşılayabilirken onun çağdaşı olan diğer toplum ise gelişmelerden uzak ilkel bir yaşam biçimiyle yaşamını devam ettirmektedir.

“... Ol şehrüñ halḳı cümle 'uryān yürürlerdi. Eger erleri ve eger "avretleri ve dizlerini örtmişlerdi anı dahı ḳoyun derisiyle... (286)"

“... Zīirā bu țā 'ife zengīler idi ve tenleri 'uryān idi. Hemān 'avret yirleri örtülmiş idi ḳoyun derisiyle... (288)"

Çölde seyahat eden kahramanların çizmesi zaman zaman parçalanır ve yalın ayak dolaşmaya mecbur kalırlar. Yine o dönemin giysilerinden olan ve günümüzde giyilmeye devâm eden câme-i harîr, kabâ-yı harîr, şalvar, pîrâhen, abâ gibi giysiler hikâyede karşımıza çıkan diğer giysilerden bir kismidir:

“... ayagiında mūzesi dahı ıāre pāre olup yalın ayak ḳaldı... (216)"

“... yüz gulām-1 sīmīn-ten ve sỉb-z̧eḳan ellerinde birer dāne boḳça ve cāme-i harîirile pür țururlardı... (593)"

“... pīrāheniyle şalvārı hod āftābuñ tābından ve tìg -i tīzinden pāre pāre olup 'uryān kalmışdı. Ol gūsfend-i deştīnüñ postıyla 'avretin örtmişdi ve nīmçe zırhın pirehen yirine giymişdi... (319)"

“... Muhtār şalvārında bir ḩancer-i ābdār pinhān itmişdi...(262)"

“... yüzine bir uzun ak saḳal geçürdi ve egnine bir yeñi bol ' abā giydi ve beline bir zünnār bağladı ve eline bir 'așā alup boynına çelīpā aṣd1... (271)"

“... Çün duhter çizmesin ayaġına çekdi ve kabāsın omuzına örtdi ve kemerin biline țoladı ve şemşirini hamā' il ḳıldı ve hancerin kemerine șoḳdı ve dülbendin başına giydi ve ayuñ on dördi gibi ol țaguñ ḳullesinde ḳaldı... (212)"

\section{6. Çevgân Oyunu}

Bilindiği üzere üstün hareket kabiliyeti ve güç gerektiren çevgân oyunu doğu topluluklarının ve özellikle Türklerin oynamış oldukları bir oyundur. Bu oyunda kullanılan çevgân bir çeşit sopa olup at sırtında topu hedefe atmak için kullanılan bir âlettir. Oyunda top ve çevgân bulunduğu için kimi edebî eserlerde "gûy u çevgân" şeklinde karşımıza çıkar (Pala, 2004: 102).

Kıssa-i Seyyid Cüneyd ve Reşîde-i Arab'da çevgân oyununun kahramanlar tarafından oynandığı görülür. Bazen Reşîde tarafindan bazen de Seyyid Cüneyd tarafından oynanan bu oyunun sonunda kahramanlar halkın ve hükümdârın beğenisini kazanırlar. Hikâyede gûy u çevgân ya bayram 
Özkan CİĞA - Elements Of Social Life In Kıssa-i Seyyid Cüneyd ve Reşîde-i

Arab

zamanı oynanır ya da hükümdâr, hünerli savaşçıları görmek istediği zamanlarda oynanır. Gûy u çevgân oynanırken ata binme, hızlı koşma, ok atma gibi güç ve hüner gerektiren aktiviteler de gerçekleştirilir:

“... nā-gāh Reşīe șabr idemeyüp hemān-dem bir yahşı ata süvār olup meydāna berk mișāl vardı. Hemān-dem hāne-i kemāna oḳ ḳodı ve naz̧ar-1 șavābla çeküp tīri pertāb itdi. Tĩr nişāna düşdi. Çün pādişāh u sipāh ta'accüb ḳaldılar. Yine meydāna merdāne at ș̣çratdı. Cevelān gösterüp çevgān diledi, virdiler. Çün eline çevgān alup țop çaldı ki tob havāya perrān olup nā-bedīd oldı. Tob bir să`atdan șoñra yire indi. Reşìde yine at șıçratdı. Meydān başına çevgān ile țopı eyle çaldı ki meydānuñ öte başında bulınup çıḳdı, gitdi. Kıırvān merdāneleri Reşīde'nüñ țopa çevgān çalışın görüp hezār āferīn dest-bāzūña didiler ve irādetleri bir iken biñ oldı... (405)"

\section{Mûsikî İlmi ve Âletleri}

Mûsikî ilmi günümüzde olduğu gibi geçmişte de önemli bir yer tutar. Çeşitli âlet ve makamlarla icrâ edilen ve birçok yazılı ve sözlü esere konu olan mûsikî ilmi klâsik edebiyatımızda bazen bir mazmûn olarak karşımıza çıkar. Özellikle dîvân şairleri tarafından mûsikî terimleri ve makâmlarının bir mazmûn olarak kullanıldığı görülür (Pala, 2004: 336-337; Sefercioğlu, 1999: 649-668).

Klssa-i Seyyid Cüneyd ve Reşîde-i Arab'da mûsikî ilmine değinilir ve mûsikî ilminin icrâ edildiği makâm ve âletler hakkında birçok bilgiye rastlanır. Özellikle Şeybû'nun kılık değiştirerek mutrib/ hânende şekline bürünmesi ve çeşitli makâmlarda "hoş-âvâz"la "hûbelhân" söylemesi, bazen de "mûyeger" olup taziyelerde ağıt yakması nedeniyle hikâyenin mûsikî ilmine dair pek çok unsuru barındırdığını söyleyebiliriz. Hikâyede mûsikî terimi olarak nefesli sâzlardan sûrnâ, nây/ney, nefîr, sûr, boru; vurmalı çalgilardan kûs, tabl, def, dühül, çârpâre, çegân/çegâne, nakâre, tavul, zenc, zil; telli çalgılarda çeng, tanbûr/ tanbûre, sâz, rebâb, berbat, kemânçe, kânûn gibi çalg1 âletleri geçer. Arap ve Acem havaları, Hicâz ve râst makamlarının da yer aldı̆̆ı hikâyede hānendeler ve mûsikîyi dinleyenler çoğu zaman kendinden geçerek semâ'a veya raksa girerler:

“... Şeybū-yı hịile-bāz sāzda ve āvāzda bì-naz̄îr idi ve 'ilm-i mūsıkịide habīir idi. țanbūresin perdāz idüp ol maḥbūb-1 gazāle münāsib hū̄bgazazeller oḳumag̉a ser-āàāa eyledi. Rāstdan girüp cemī' makāāmātı hū̄btahrī̄ātıla seyirler idüp gelüp gine rāstda ḳarār itdi. Çün Şeybū hoşāvāz ile ol duhter-i dil-nüvāza naz̧ar itdi. Gördi ruḩ-1 ferruhlarında 'alāmet-i beşāşet var, yine țanbūresin eline alup gūş-māl itdi ki dā 'irei perdeden tecāvüz itmeye. Şeybū şāh-āvāz ile dahı hịcāz-1 nevāda maḳāma āgāa itdi. Şol havālarda pervāz eyledi ki duhter-i dil-nüvāza bì-ihtiyār hezār 'işve vü nāzla țurı gelüp rakșa girdi.... (283-284)"

“... Yine Şeybū-yı hoş āvāz eline bir Türkī nāyı aldı ve bir șoḥbete āgāà itdi ki işidenlerüñ göñlini göyündürdi. Hezār bār evvelki șoḥbetlerinden yigdi. Manșūr derūn-1 dilden āh idüp eyitdi: Ey kāşki bu muțrib-i hoş-nevā benüm elüme gireyditā og̉luma göndereydüm. Aña daḩı șoḥbetler eyleyeydi, didi. Andan șoñra Reşide-i dil-ārāma 
göndereydüm, didi tā bir iki üç gün anı ḩoş țutaydı. Şāyed ki anuñ serd țaş gibi göñli nerm olaydı. Oggluma merḥamet ideydi ve mülā’imet göstereydi. Og̉lum dahı andan murādın göreydi. Manșūr bu sözde iken Şeybū-yı şirīn-kār çün nāy-1 'Irāḳị eline aldı ve nevā-yı 'Acem ve 'Irāḳ'da bir șoḥbet eyledi ki Manșūr ile güyegüsine bīihtiyār girye vü zār düşdi ve eyitdiler: Ey Huālkḳ'uñ mahlūḳı eger dīvseñ ve eger perīseñ ve eger bizüm gibi insān iseñ bizden gizlenme. Bize gel kim dil-i cānumuzı nār-1 nāy-1 'Irāḳ’uñla iḥrāḳ idüp biryān eyledüñ... (648-649)"

“... Sūrnālar ve nakāreler ve tavullar ve zencler çalarlardı ve bir og̉lı var idi. Hezār-bār atasından sehmnākdı.Bir duhteri daḩı var idi. Begāayet hūūb-rūy idi. Ammā ḳulag̉ı büyük idi. Ataları bile deryā kenārına geldiler. Ebū Ḥaf̣s-1 Kūfí eydür: 'Ālemde hīç kimesne muțrıblık itmegi kilīm-gūş gibi bilmezdi. Ġāyet hoş-āvāzlardı ve 'ilm-i mūsıḳide mümtāzlardı... (513-514)"

\section{Nevrûz Kutlamaları}

Kelime anlamı "yeni gün” olan nev-rûz "Güneşin hamel/koç burcuna girdiği gün olup eski Mart'1n dokuzu (şimdiki 21 Mart) olarak bilinir (Pala, 2004: 357)." Hem Fars kültüründe hem de Türk kültüründe büyük bir öneme hâiz olan nevrûza ait efsânevî inanışlar mevcuttur. Bu inanışlar dolayısıyla çeşitli şekillerde kutlanan nevrûzda eski İran şahları tahta oturarak ihtiyaç sahiplerinin ihtiyaçlarını karşılar, mahpusları serbest bırakır, içki ve eğlence ile vakit geçirir (Pala, 2004: 357-358). Günümüzde de devâm eden nevrûz kutlamalarında çeşitli spor aktiviteleri yapılır, geleneksel kıyâfetler giyilerek müzik ve dans gösterileri yapılır, ateş üzerinden atlanılır, demir dövülür ve yumurta tokuşturulur.

Hikâyede nev-rûz bir bayram günü olarak kutlanır. Bu bayramda hükümdâr kutlamaları izlemek üzere taht-1 zerrîn üzerinde oturur, halk ise meydanlarda güreşir, ok atar, ata biner ve gûy u çevgân oynar:

“... Bir gün Cüneyd’le Kāậi Ṭarțūs pādişāhınuñ seyrānına ve meydānına çıḳdılar. Bir galaba enbūh-1 'azịm gürūh gördiler. İlerü varup bir şahșa șordılar ki bu cem 'iyyet nedür? Ol şahș eyitdi: Güreşci pehlevānlar gelmişdür. Anlaruñ hengāmesidür ve hem bugün nev-rūz1 dil-fürūzdur ve pādişāhumuz dahı andadur. Güreş temāşāsin eyler. Cüneyd'le Kāạī halḳ içinden meydān yüzine vardılar. Pādişāhı gördiler, bir civān-1 meh-likāa cemāl-i nūrından meydān pür-żiyā tahtt-1 zerrīn üzre nişīn ve ețrāfında zerrīn-kemer gulāmlar gün yüzlüler, lațịf endāmlular ve lebleri şekerlüler ve gözleri bādāmlular el kavuşurup ḳarşu durur. Cüneyd'üñ gaayreti țamarındaġı kanlar cūşa geldi, hemāndem șoyundı. Sahtiyān tumān giyüp 'azm-i meydān itdi ve cezm eyledi ki cümlesin bașa. Halāyık Cüneyd'üñ ḳadd u ḳāmetin ve ṣalābetin ve nehābetin görüp ta' accübde ḳaldılar... (234)"

“... Cümle cihān halḳına lā-büddür kim sizüñ dizüñüzi ve rikābuñuzı öpeler ve ol sā̄ at ki siz pehlevānlarla rūz-1 nev-rūzda güreş țutduñuz sizüñ ḳaddüñüzi ve kāmetüñüzi görüp gümān iletdüm... (240)" 
Özkan CİĞA - Elements Of Social Life In Kıssa-i Seyyid Cüneyd ve Reşîde-i

Arab

“... İttifāk bir gün rūz-1 ' id idi ve pādişāh-1 Ḳırvān meydān hevesin buyurd1. Çün meydāna çıḳdılar. Ol şāhuñ süvār-ı nāmdārlar ki esb-i tāzīlere süvār olup ol yazıda gūy çevgān ele alup ve hezār gūne bāzī gösterdiler... (404-405)"

\section{At Evcilleştirme}

Geçmişte yaşayan topluluklarda ve özellikle Bozkır hayatını benimseyen Türklerde atın binek hayvanı olarak kullanıldığı bilinmektedir. Türklerin bulunduğu coğrafî ve siyasî konum itibarıyla atlar; Türklerin yaşam tarzına bağlı olarak onların hayatlarının hemen her anında var olduğu görülür. Gıda, tarım, ulaşım ve savaş aracı olarak çok önemli roller üstlenmiş olan atların, birçok araştırmacıya göre ilk defa Orta Asya Türkleri tarafindan evcilleştirildiği söylenir. Tarihte kurulan Türk devletlerinin kuruluş ve yükseliş dönemlerinde büyük rol oynayan atların Türk kültüründe ve edebiyatındaki yeri ve önemi küçümsenmeyecek kadar büyüktür. Türkler tarih içinde at ile ilgili pek çok atasözü ve deyimler (Sertkaya, 1995: 25-30) kullanır, Divanü Lügati’t Türk (Çınar, 1995: 147-155) ve Manas destanı (Mokeyev, 1995: 289-296) gibi eserlerde atlarla ilgili tabirlere ve at isimlerine sıkça yer verir. Masallarda atları bir motif (Sakaoğlu, 1995: 282288) olarak işleyen Türkler, atlara sanatta da geniş yer verir (Esin, 1995: 5490) ve bir edebî tür olarak esbiye/ rahşiyeleri (Bilgin, 1995: 276-279) yazar. At yetiştiriciliğine büyük önem veren Türkler günümüzde ata sporu olarak biniciliği ve cirit oyununu da devam ettirir.

Klssa-i Seyyid Cüneyd ve Reşîde-i Arab'da da atın evcilleştirilmesiyle ilgili teknik detaylara değinildiği görülür. Hikâyede atların cüssesi ve hırçınlığı mübalağa ile anlatıldıktan sonra kahramanlar tarafından atın nasıl uysal hâle gelerek eyerlendiği hakkında bilgi verilir:

“... Bir zencīir ḳaldı anuñ dahı ucını Mukātil'üñ eline virdiler. Çün Muḳātil atuñ kāâtına geldi. Diledi ki elini atuñ boynı üzerine ḳoya. Nāgāh ol esb-i deryāyī süheyl idüp yirinden 'ukāa gibi șiçradı ve kendüzin zengīnüñ üzerine pertāb itdi ve hezār na' ra urup țurdı. At dahı şīr-i jiyān gibi añrayup zengīnüñ eñsesin aġzına aldı ve yirinden kaldurup yire çaldı. Zengī kendüzinden gitdi. Çün at kendüzin bendden boş gördi, cūş idüp ḩalḳa hamle eyledi. Halk dahı atı ortaya alup halḳa șadmetinden nefret idüp ata yol virdiler ki vara șaḥāya gide. Seyyid Cüneyd Şeybū dahı temāşā eylerdi. Çün bu halḳuñ nefretin ve zengīnün hacāletin gördiler. Ta'accüb idüp hayrete vardılar. Ammā çün at Seyyid'üñ katına geldi, Şeybū eyitdi: Ey Seyyid atı țut dahı gel. Yine yirümüze gidelüm. Nā-gāh Seyyid Cüneyd bir na' ra urup andan vardı. Sag elin uzadup atuñ yelesin țutdı ve șol elin uzadup aġzın țutdı. Andan ḳarnına bir püşt-pā ile urdı ki at arḳasın kemān gibi iki bükdi ve ḳulağı gözine bir müşt urup andan kulag̉ın eline aldı. Şöyle burdı ki at miskin ḩar gibi țurı vardı. Seyyid, Şeybū'dan tāziyāne diledi. Şeybū daḩı șunu virdi. Seyyid hemān eyersüz ve uyansuz üzerine süvār olup meydāna șıçratdı. Şol ḳadar yeldürdi ki at 'araḳa gark olup süst oldı. Andan șoñra zīn licām getürüp atı eyerleyüp başına uyan geçürdi ve yine rikāba ḳadem ḳoyup 
Özkan CíĞA - Kıssa-i Seyyid Cüneyd ve Reşîde-i Arab’da Sosyal Hayata Dair

Unsurlar

süvār oldı dahı meydānuñ öte başından beri başından öte başına şol kadar segirtdi ki at zebūn oldı... (445-447)"

\section{Sonuç}

Görüldüğü üzere bu çalışmada, mensur olarak kaleme alınan Klssa-i Seyyid Cüneyd ve Reşîde-i Arab'da yer alan sosyal hayata dair unsurlar on dokuz başlık altında değerlendirildi. Hikâyede dînî ve tarihî şahsiyetlerin yanı sıra olağanüstü özelliklere sahip varlıkların kurguya dahil edilmesi ve buna bağl1 olarak hem gerçek hem de olağanüstü nitelikte bulunan mekânların hikâyede bir arada bulunması nedeniyle bir kısmı gerçek ve bir kısmı fantastik bir yaşam biçimi ortaya çıkmışıtır. Sosyal hayata dair unsurlar tespit edilirken genellikle gerçek yaşama dair izlenimler dikkate alınmıştır. Ancak hikâyenin yazıldığı dönemden esinlenerek kurguya dahil edilen kültür zenginliğini göstermek adına bazen olağanüstü nitelikteki varlıkların kültür öğelerine de yer verilmiştir. Hikâyedeki olayların geniş bir coğrafyada vuku bulması nedeniyle birbirinden farklı ancak aynı çağda yaşayan toplulukların gelenek görenek, yaşam tarzı ve inançlarına dair pek çok farklılık tespit edildi. $\mathrm{Bu}$ farklılıkların kılık kıyafet tercihlerinde, yiyecek ve içecek seçimlerinde, eş seçiminde, evlilik durumunda ve ağıtlarda belirginleştiği görüldü. Bazı topluluklar tarafından çok değerli görülen eşyaların, elmas veya zümrüt gibi değerli taşların bazı topluluklar tarafından sıradan bir nesne olarak algılandığ 1 tespit edildi. Yine aynı şekilde kimi varlık veya insanlar tarafından değer atfedilen şahısların üzerine altın, gümüş veya değerli taşlar saçılırken kimi varlık veya insanlar tarafından değer atfedilen şahısların üzerine meyvelerin ve yiyeceklerin saçıldığına şahit olundu. Tarihî kalıntılar vasıtasıyla günümüze ulaşan kimi savaş araç gereçlerinin hikâyede nasıl ve ne amaçla kullanıldıkları bilgisine ulaşıldı. Surları yıkmak için tasarlanan mancınık sisteminin işleyişi, yine aynı şekilde surların dibini oymaya çalışan külüngzenlerin taş veya oklara karşı korunması amacıyla bir arabanın yapılışı hakkında fikir sahibi olundu. Ayrıca henüz ok ve yay savaşını bilmediği için kurgudaki kahramanın kullandığ 1 ok ve yayı kendi hükümdarlarına anlatan siyahların bu savaş âleti karşısındaki şaşkınlıkları dikkatlerden kaçmaz.

\section{Kaynakça}

Arslan, M. U. (2015). Türk Edebiyatı'nda Temîmü'd-Dârî Hikâyeleri (İnceleme-Metin). (Yayınlanmamış Doktora Tezi). Diyarbakır: Dicle Üniversitesi SBE.

Atar, F. (2007). "Nikâh". TDV İslam Ansiklopedisi, (XXXIII, 112-117). İstanbul: TDV Yayınları.

Ayanoğlu, İ. F. (1974). Okmeydanı ve Okçuluk Tarihi. Ankara: Vakıflar Genel Müdürlügüü.

Batislam, H. D. (2006). "Hasbihâllerdeki Sosyal Tarih Öğeleri”. Türk Dili Dil ve Edebiyat Dergisi, cilt. XCII, ss. 557-563. 
Özkan CïĞA - Elements Of Social Life In Kıssa-i Seyyid Cüneyd ve Reşîde-i Arab

Bilgin, O. (1995). "Türk Edebiyatında Rahşiyeler”. Türk Kültüründe At ve Çağdaş Atç1lık Sempozyumu, s. 276-279. İstanbul: Resim Matbaacılık A. Ş.

Ciğa, Ö. (2016). "Vâhidî’nin Kıssa-i Seyyid Cüneyd ve Reşîde-i Arab ve Sergüzeşt-i Îşân Tercümesi Üzerine". Dicle Üniversitesi SBE Dergisi (DÜSBED), ISSN: 1308-6219 Nisan Y11: 8 Sayı: 16 s. 442-450, Türkiye.

Ciğa, Ö. (2018). Kıssa-i Seyyid Cüneyd ve Reşîde-i Arab Tercümesi (İnceleme-Metin). (Yayınlanmamış Doktora Tezi). Adıyaman: Adıyaman Üniversitesi SBE.

Çakır, M. ve Hanife Koncu (2010). XVI. Yüzyıldan Bir Aşk Hikâyesi Medhî'nin Şîr-i Dilîr Bâ-Mihr-i Münîr'i. İstanbul: Kesit Yayınları.

Çaldak, S. (2010). Nergisî ve Nihâlistân'ı. İstanbul: Kesit Yayınları.

Çavuşoğlu, M. (1971). Necâtî Bey Divânı'nın Tahlili. İstanbul: Milli Eğitim Basımevi.

Çınar, A. (1995). “Divanu Lügati’t- Türk’te At Kültürü”. Türk Kültüründe At ve Çağdaş Atçılık Sempozyumu, s. 147-155. İstanbul: Resim Matbaacılik A. Ş.

Dilçin, C. (1991). Mes'ûd bin Ahmed Süheyl ü Nev-bahâr (İnceleme-MetinSözlük). Ankara: Atatürk Kültür Merkezi Yayınları.

Erbay, H. vd. (2014). Dede Korkut Kitabı han'im hey. Ankara: TOBB.

Esin, E. (1995). "Türk Sanatında At" Türk Kültüründe At ve Çağdaş Atçılık

Sempozyumu, s. 54-90, İstanbul: Resim Matbaacilık A. Ş.

İnan, M. (1992). Osmanlı İmparatorluğunda Okçuluk Sporu ve Temel Teknikleri. (Yayınlanmamış Yüksek Lisans Tezi). İstanbul: Marmara Üniversitesi Sağlık Bilimleri Enstitüsü.

İsen, M. (1994). Acıyı Bal Eylemek Türk Edebiyatında Mersiye. Ankara: Akçağ Yayınları.

Karataş, L. (2006). Nedîm Dîvânında Lâle Devri Sosyal Hayatının İncelenmesi. (Yayınlanmamış Yüksek Lisans Tezi). İzmir: Dokuz Eylül Üniversitesi Eğitim Bilimleri Enstitüsü.

Kurnaz, C. (1996). Hayâlı̂ Bey Divânı'nın Tahlili. İstanbul: Milli Eğitim Basımevi.

Mokeyev, E. (1995). "Manas Destanında At İsimleri” Türk Kültüründe At ve Çağdaş Atçılık Sempozyumu, s. 289-296, İstanbul: Resim Matbaacılık A. Ş.

Öbek, A. İ. (1995). Divan Şiirinde Dinî ve Sosyal Konulu Rübailer. İstanbul: İnsan Yayınları.

Özkan, Ö. (2007). Divan Şiirinin Penceresinden Osmanlı Toplum Hayatı. İstanbul: Kitabevi Yayınları.

Pala, İ. (2004). Ansiklopedik Divan Şiiri Sözlüğü. İstanbul: Kap1 Yayınları. 
Özkan CİĞA - Kıssa-i Seyyid Cüneyd ve Reşîde-i Arab'da Sosyal Hayata Dair Unsurlar

Sakaoğlu, S. (1995). "Türk Masallarında At Motifi”. Türk Kültüründe At ve Çağdaş Atç1lık Sempozyumu, s. 282-288, İstanbul: Resim Matbaacılık A. Ş.

Samsakçı, M. (2012). "Türk Kültür ve Edebiyatında Tuz ve Tuz-Ekmek Hakkı". İstanbul Üniversitesi Edebiyat Fakültesi Türk Dili ve Edebiyatı Dergisi, 36 (36), 181-199.

Sefercioğlu, M. N. (1999). "Dîvan şiirinde Mûsikî İle İlgili Unsurların Kullanılışı”. Osmanlı Ansiklopedisi, (XIX, 649-668). Ankara: Yeni Türkiye Yayınları.

Sefercioğlu, M. N. (2001). Nev'î Divanı'nın Tahlîli. Ankara: Akçă̆ Yayınları.

Serdaroğlu, V. (2006). Sosyal Hayat Işı̆̆ında Zâtî Divanı. İstanbul: İSAM.

Sertkaya, O. F. (1995). "Eski Türk Kültüründe At”. Türk Kültüründe At ve Çağdaş Atçılık Sempozyumu, s.25-30, İstanbul: Resim Matbaacılık A. Ş.

Şen, F. M. (2007). "Eski Türk Edebiyatında Sosyal Hayat Çalışmaları". Türkiye Araştırmaları Literatür Dergisi, Cilt 5, Say1 9, Sayfa 467-506.

Tarama Sözlüğü (2009). Ankara: Türk Dil Kurumu Yayınları.

Tolasa, H. (2001). Ahmet Paşa 'nın Şiir Dünyası. Ankara: Akçağ Yayınları.

Tuğluk, İ. H. (2009). "Edebiyat-Toplum İlişkisi: Lâmekânî’nin Bir Gazeline Göre 17. Yüzyıl Osmanlı Toplumu”. Modern Türklük Araştırmaları Dergisi, Cillt 6, Sayı 1, ss. 81-90.

Türkçe Sözlük (2011). Ankara: Türk Dil Kurumu Yayınları. 